\title{
Gas-Phase Acidities of Cysteine-Polyglycine Peptides: The Effect of the Cysteine Position
}

\author{
Kiran Kumar Morishetti, Betty De Suan Huang, Jessica Marney Yates, \\ and Jianhua Ren \\ Department of Chemistry, University of the Pacific, Stockton, California, USA
}

\begin{abstract}
The sequence and conformational effects on the gas-phase acidities of peptides have been studied by using two pairs of isomeric cysteine-polyglycine peptides, CysGly ${ }_{3,4} \mathrm{NH}_{2}$ and $\mathrm{Gly}_{3,4} \mathrm{CysNH}_{2}$. The extended Cooks kinetic method was employed to determine the gas-phase acidities using a triple quadrupole mass spectrometer with an electrospray ionization source. The ion activation was achieved via collision-induced dissociation experiments. The deprotonation enthalpies $\left(\Delta_{\text {acid }} H\right)$ were determined to be $323.9 \pm 2.5 \mathrm{kcal} / \mathrm{mol}\left(\mathrm{CysGly}_{3} \mathrm{NH}_{2}\right), 319.2 \pm$ $2.3 \mathrm{kcal} / \mathrm{mol}\left(\mathrm{CysGly}{ }_{4} \mathrm{NH}_{2}\right), 333.8 \pm 2.1 \mathrm{kcal} / \mathrm{mol}\left(\mathrm{Gly}_{3} \mathrm{CysNH}_{2}\right)$, and $321.9 \pm 2.8 \mathrm{kcal} / \mathrm{mol}$ $\left(\mathrm{Gly}_{4} \mathrm{CysNH}_{2}\right)$, respectively. The corresponding deprotonation entropies $\left(\Delta_{\text {acid }} S\right)$ of the peptides were estimated. The gas-phase acidities $\left(\Delta_{\text {acid }} G\right)$ were derived to be $318.4 \pm 2.5 \mathrm{kcal} / \mathrm{mol}$ $\left(\mathrm{CysGly}{ }_{3} \mathrm{NH}_{2}\right), 314.9 \pm 2.3 \mathrm{kcal} / \mathrm{mol}\left(\mathrm{CysGly}{ }_{4} \mathrm{NH}_{2}\right), 327.5 \pm 2.1 \mathrm{kcal} / \mathrm{mol}\left(\mathrm{Gly}_{3} \mathrm{CysNH}_{2}\right)$, and $317.4 \pm 2.8 \mathrm{kcal} / \mathrm{mol}\left(\mathrm{Gly}_{4} \mathrm{CysNH}_{2}\right)$, respectively. Conformations and energetic information of the neutral and anionic peptides were calculated through simulated annealing (Tripos), geometry optimization (AM1), and single point energy calculations (B3LYP/6-31+G(d)), respectively. Both neutral and deprotonated peptides adopt many possible conformations of similar energies. All neutral peptides are mainly random coils. The two C-cysteine anionic peptides, $\mathrm{Gly}_{3,4}(\mathrm{Cys}-\mathrm{H})^{-} \mathrm{NH}_{2}$, are also random coils. The two $\mathrm{N}$-cysteine anionic peptides, (Cys-H) ${ }^{-} \mathrm{Gly}_{3,4} \mathrm{NH}_{2}$, may exist in both random coils and stretched helices. The two $\mathrm{N}$-cysteine peptides, CysGly ${ }_{3} \mathrm{NH}_{2}$ and $\mathrm{Cys} \mathrm{Gly}_{4} \mathrm{NH}_{2}$, are significantly more acidic than the corresponding C-terminal cysteine ones, $\mathrm{Gly}_{3} \mathrm{CysNH}_{2}$ and $\mathrm{Gly}_{4} \mathrm{CysNH}_{2}$. The stronger acidities of the former may come from the greater stability of the thiolate anion resulting from the interaction with the helix-macrodipole, in addition to the hydrogen bonding interactions. (J Am Soc Mass Spectrom 2010, 21, 603-614) (c) 2010 American Society for Mass Spectrometry
\end{abstract}

$\mathrm{P}$ eptides and proteins are known to carry multiple charges in their native state under physiologic conditions through protonation and deprotonation of basic and acidic amino acid residues, respectively [1]. The charge states are often correlated to the structures, properties, and biological functions of the proteins. Studies have shown that charged groups close to the ends of helices were found to be an important determinant of the stability of the helices [2-6]. The extents of protonation and deprotonation are directly related to the acid-base properties of individual amino acid residues. Interestingly, an amino acid residue located at different positions in a folded protein often exhibits different degrees of acidity or basicity. For example, an acidic residue, such as cysteine or aspartic acid, located at or near the $\mathrm{N}$-terminus of a helix is often more acidic than that at or near the $C$-terminus [5, 7-11]. A wealth of studies on the acid-base properties of helical peptides have been carried out in condensed phase, in particular in aqueous solutions [11-13]. How-

Address reprint requests to Professor J. Ren, Department of Chemistry, University of the Pacific, 3601 Pacific Ave., Stockton, CA 95211, USA. E-mail: jren@pacific.edu ever, the results are complicated by solvent effects [12]. Solvent effects are especially significant in water-based systems. In fact, most of the active sites in proteins are located near the interior region where solvent effects from water molecules have been minimized [14, 15]. To understand intrinsic acid-base properties of peptides and proteins, it is important to perform studies in an environment in which solvents can be eliminated. The introduction of electrospray ionization (ESI) by Fenn and coworkers has opened the door for exploring the properties of peptides and proteins in the gas-phase [16, 17].

The acid-base properties of amino acid residues also play important roles in the gas-phase ion chemistry of peptides and proteins, including the ion intensities in different ionization processes, the fragmentation mechanisms under tandem mass spectrometry conditions, and hydrogen/deuterium exchange patterns [18-32]. In recent years, many of the gas-phase studies have focused on the determination of the proton affinities (and gas-phase basicities) of amino acids and peptides [3345]. Although the gas-phase acidities of isolated amino acids have been studied extensively [46-54], and the apparent acidities of multiply charged peptides have 
been reported [55], the information on the acidities of gas-phase neutral peptides is very limited $[56,57]$.

In recent years, we have started to investigate the helix conformational effects on the gas-phase acidities of peptides by using a series of polyalanine- and polyglycine-based model peptides with cysteine as the acidic probe $[6,56,57]$. All of the peptides are amidated at the C-terminus, so that the thiol group $(\mathrm{SH})$ of the cysteine residue is expected to be the only acidic site. Previous studies carried out in both the condensed phase and gas phase have shown that polyalanine peptides have strong propensities for helices, while polyglycine analogues prefer globular conformations [58-61]. We have reported the determination of the gas-phase acidities of four cysteine-polyalanine peptides, CysAla ${ }_{3,4} \mathrm{NH}_{2} \quad\left(\mathrm{CA}_{3,4} \mathrm{H}\right)$ and $\mathrm{Ala}_{3,4} \mathrm{CysNH}_{2}$ $\left(\mathrm{A}_{3,4} \mathrm{CH}\right)$. We found that the two N-terminal cysteine peptides, $\mathrm{CA}_{3,4} \mathrm{H}$, were significantly more acidic than the corresponding $\mathrm{C}$-terminal cysteine ones, $\mathrm{A}_{3,4} \mathrm{CH}$, by 10 and $5 \mathrm{kcal} / \mathrm{mol}$, respectively. The high acidities of the former are likely due to the helical conformational effects for which the thiolate anion may be strongly stabilized by the interaction with the helix macrodipole.

In this article, we report the results from the mass spectrometry measurements and computational studies of four cysteine-polyglycine peptides, CysGly ${ }_{3,4} \mathrm{NH}_{2}$ $\left(\mathrm{CG}_{3,4} \mathrm{H}\right)$ and $\mathrm{Gly}_{3,4} \mathrm{CysNH}_{2}\left(\mathrm{G}_{3,4} \mathrm{CH}\right)$, scheme 1 .

\section{Experimental}

\section{The Kinetic Method}

The gas-phase acidities and the related thermochemical quantities were determined using the extended kinetic method. The kinetic method introduced by Cooks and coworkers has been successfully applied to a wide range of systems for the determination of various thermochemical properties, such as gas-phase acidity, proton affinity, metal ion affinity, electron affinity, and ionization energy [35, 37, 38, 62-67]. Because of the nonvolatile and thermally labile nature of peptides, the kinetic method is the most practical approach available now to produce reasonably accurate acid-base thermochemical quantities of peptides [33]. The gas-phase acidity $\left(\Delta_{\text {acid }} G\right)$ is defined as the Gibbs free-energy change for the following reaction (generally at $298 \mathrm{~K}$ ), eq 1 . The deprotonation enthalpy $\left(\Delta_{\text {acid }} H\right)$ and deprotonation entropy $\left(\Delta_{\text {acid }} S\right)$ are the enthalpy and entropy changes of the same reaction.

$$
\mathrm{AH} \rightarrow \mathrm{A}^{-}+\mathrm{H}^{+}
$$
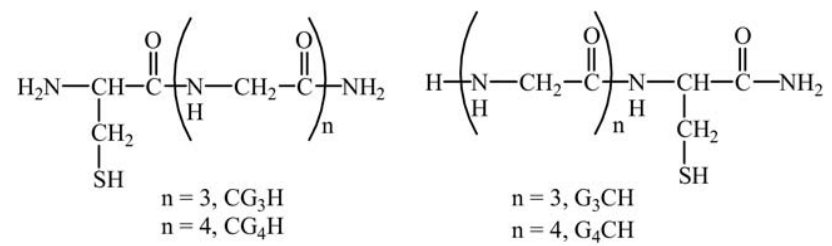

Scheme 1

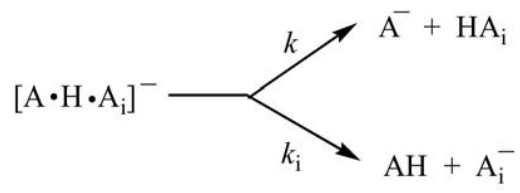

Scheme 2

The determination of the gas-phase acidity of a peptide $(\mathrm{AH})$ starts with the formation of proton-bound dimeric anions, $\mathrm{A}^{-} \ldots \mathrm{H}^{+} \ldots \mathrm{A}_{\mathrm{i}}^{-}\left(\left[\mathrm{A} \cdot \mathrm{H} \cdot \mathrm{A}_{\mathrm{i}}\right]^{-}\right)$in the ESI source of the mass spectrometer, where $\mathrm{A}^{-}$is the deprotonated form of the peptide, $\mathrm{AH}$, and $\mathrm{A}_{\mathrm{i}}^{-}$is the deprotonated form of the reference acids, $\mathrm{A}_{\mathrm{i}} \mathrm{H}$. All of the reference acids have known gas-phase acidities. The proton-bound dimeric anions dissociate in the collisioninduced dissociation (CID) experiments to yield the corresponding monomeric anions, $\mathrm{A}^{-}$and $\mathrm{A}_{\mathrm{i}}^{-}$, with rate constants of $k$ and $k_{\mathrm{i}}$, respectively, Scheme 2 .

The abundance ratio of the $\mathrm{A}^{-}$and $\mathrm{A}_{\mathrm{i}}^{-}$fragment ions resulting from the CID experiments represents an approximate measure of the rate constant ratio $\left(k / k_{\mathrm{i}}\right)$ of the dissociations leading to these fragment ions. With the assumption that there are no reverse activation barriers and also by considering situations where the reference acids and the peptide all have very similar structures, the gas-phase acidity can be obtained according to the relationship given in eq 2, where $\Delta_{\text {acid }} G_{i}$ is the gas-phase acidity of the reference acid $\left(\mathrm{A}_{\mathrm{i}} \mathrm{H}\right)$ and $\Delta_{\text {acid }} G$ is the gas-phase acidity of the peptide $(\mathrm{AH}), R$ is the universal gas constant, and $T_{\text {eff }}$ is the effective temperature of the system. The effective temperature is an empirical parameter that depends on several experimental variables and properties of the proton-bound dimers [68-74].

$$
\operatorname{In}\left(\frac{k}{k_{\mathrm{i}}}\right) \approx \operatorname{In}\left(\frac{\mathrm{A}^{-}}{\mathrm{A}_{\mathrm{i}}^{-}}\right) \approx \frac{\Delta_{\mathrm{acid}} G_{i}-\Delta_{\mathrm{acid}} G}{R T_{\mathrm{eff}}}
$$

Because the structure of the peptide is much different from those of the reference acids, the entropic contribution needs to be considered. The entropic contribution is the difference of the activation entropies between the two competing dissociation channels shown in Scheme 2, $\Delta(\Delta S)=\Delta S^{\neq}-\Delta S^{\neq}{ }_{\mathrm{i}}$. Since the reference acids all have similar structures, the term $\Delta(\Delta S)$ can be assumed to be constant. Under the assumption of the negligible reverse activation barriers, $\Delta(\Delta S)$ can be related to the deprotonation entropies of the two acids ( $\mathrm{HA}$ and $\mathrm{HA}_{\mathrm{i}}$ ), $\Delta(\Delta S) \approx \Delta_{\text {acid }} S-\Delta_{\text {acid }} S_{\mathrm{i}}$. By using the thermodynamic relationship, $\Delta_{\text {acid }} G=\Delta_{\text {acid }} H-T_{\text {eff }} \Delta_{\text {acid }} S$, eq 2 is converted to eq 3 , where $\Delta_{\text {acid }} H_{\mathrm{i}}$ is the deprotonation enthalpy of the reference acid $\left(\mathrm{A}_{\mathrm{i}} \mathrm{H}\right)$ and $\Delta_{\text {acid }} H$ is the deprotonation enthalpy of the peptide $(\mathrm{AH})$,

$$
\operatorname{In}\left(\frac{\left[\mathrm{A}^{-}\right]}{\left[\mathrm{A}_{\mathrm{i}}^{-}\right]}\right)=\frac{\Delta_{\text {acid }} H_{\mathrm{i}}}{R T_{\mathrm{eff}}}-\left[\frac{\Delta_{\text {acid }} H}{R T_{\text {eff }}}-\frac{\Delta(\Delta S)}{R}\right]
$$


Under such circumstances, the natural logarithm of the ion intensity ratio of the fragment ions has a linear correlation to $\Delta_{\text {acid }} H_{\mathrm{i}}$. By plotting $\ln \left(\left[\mathrm{A}^{-}\right] /\left[\mathrm{A}_{\mathrm{i}}^{-}\right]\right)$measured at different collision energies against the values of $\Delta_{\text {acid }} H_{\mathrm{i}}$, a set of linear plots would be obtained. The slopes correspond to $1 / R T_{\text {eff }}$ and the intercepts correspond to the term shown in the squared bracket in eq 3. The resulting intercepts are then plotted against the slopes. The new linear regression line would give $\Delta_{\text {acid }} H$ from the slope and $\Delta(\Delta S)$ from the intercept. However, the newly obtained linear regression line from such data often shows an almost perfect linear correlation coefficient that may lead to underestimated experimental uncertainties. To decrease the severity of this problem, Armentrout has suggested using $\Delta_{\text {acid }} H_{\mathrm{i}}$ - $\Delta_{\text {acid }} H_{\text {avg }}$ to replace $\Delta_{\text {acid }} H_{\mathrm{i}}$, where $\Delta_{\text {acid }} H_{\text {avg }}$ is the average gas-phase acidity of all the references used for a particular peptide $[75,76]$. Then eq 3 is converted to eq 4 , where $\ln \left(\left[\mathrm{A}^{-}\right] /\left[\mathrm{A}_{\mathrm{i}}^{-}\right]\right)$has a linear relationship with $\Delta_{\text {acid }} H_{\mathrm{i}}-\Delta_{\text {acid }} H_{\text {avg }}$.

$$
\begin{aligned}
& \operatorname{In}\left(\frac{\left[\mathrm{A}^{-}\right]}{\left[\mathrm{A}_{\mathrm{i}}^{-}\right]}\right)=\frac{\Delta_{\text {acid }} H_{\mathrm{i}}-\Delta_{\text {acid }} H_{\text {avg }}}{R T_{\text {eff }}}-\left[\frac{\Delta_{\text {acid }} H-\Delta_{\text {acid }} H_{\text {avg }}}{R T_{\text {eff }}}\right. \\
& \left.\quad-\frac{\Delta(\Delta S)}{R}\right]
\end{aligned}
$$

Plotting of $\ln \left(\left[\mathrm{A}^{-}\right] /\left[\mathrm{A}_{\mathrm{i}}^{-}\right]\right)$measured at different collision energies against $\Delta_{\text {acid }} H_{\mathrm{i}}-\Delta_{\text {acid }} H_{\text {avg }}$ yields a set of straight lines with slopes of $1 / R T_{\text {eff }}$ and intercepts of $-\left[\Delta_{\text {acid }} H-\Delta_{\text {acid }} H_{\text {avg }}\right] / R T_{\text {eff }}-\Delta(\Delta S) / R$. If these intercepts are plotted against the corresponding slopes, one obtains a new linear plot with $\Delta_{\text {acid }} H-\Delta_{\text {acid }} H_{\text {avg }}$ as the slope and $\Delta(\Delta S) / R$ as the intercept. The value of $\Delta_{\text {acid }} H$ is then obtained from the slope, since $\Delta_{\text {acid }} H_{\text {avg }}$ is known. The entropy term, $\Delta(\Delta S)$, is obtained from the intercept. Because reference acids all have similar deprotonation entropies as shown in Table 1, the average deprotonation entropy, $\Delta_{\text {acid }} S_{\text {avg }}$ may be used to replace $\Delta_{\text {acid }} S_{\mathrm{i}}$. We would have the relationship, $\Delta(\Delta S) \approx$ $\Delta_{\text {acid }} S-\Delta_{\text {acid }} S_{\text {avg }}$. The deprotonation entropy $\left(\Delta_{\text {acid }} S\right)$ of each peptide can then be obtained. With the deprotonation enthalpy and entropy available, we can derive the gas-phase acidity $\left(\Delta_{\text {acid }} G\right)$ of the peptide by using the thermodynamic relationship shown in eq 5 , where $T=298 \mathrm{~K}$.

$$
\Delta_{\text {acid }} G=\Delta_{\text {acid }} H-T\left(\Delta_{\text {acid }} S\right)
$$

The uncertainty of the average acidity $\left(\Delta_{\text {acid }} H_{\text {avg }}\right)$ was calculated as the root sum square of the random and systematic errors. For a set of five reference acids, the random error was treated as the averaged uncertainty of the reference acids $( \pm 2.2 \mathrm{kcal} / \mathrm{mol})$ divided by the square root of the number of the reference acids, $(2.2 / \sqrt{ } 5)=0.98 \mathrm{kcal} / \mathrm{mol}$, and the systematic error was assigned as $\sqrt{ } 2.2=1.5 \mathrm{kcal} / \mathrm{mol}$. The root sum square of the random and systematic errors yielded $\mathrm{V}\left(0.98^{2}+\right.$ $1.5^{2}=1.8 \mathrm{kcal} / \mathrm{mol}$.

\section{Mass Spectrometry Measurements}

All experiments were carried out in a triple quadrupole mass spectrometer interfaced to an ESI source (Varian 1200L; Varian Inc., Walnut Creek, CA, USA) located in the Mass Spectrometry Facility of the Chemistry Department at the University of the Pacific. Data acquisition was controlled by using the MS Workstation software package (version 6.5). The ESI needle voltage was maintained at $-4.5 \mathrm{kV}$, and the capillary voltage was kept at -20 to $-50 \mathrm{~V}$. Nitrogen was used as the desolvation gas and compressed air was used as the nebulizer gas. The ion source and desolvation temperatures were kept at $50{ }^{\circ} \mathrm{C}$ and $200{ }^{\circ} \mathrm{C}$, respectively. The hexapole ion guide chamber has about 1 mTorr nitrogen gas. Ions generated in the ESI source are presumed to be thermalized by multiple collisions with the nitrogen molecules in the ion guide chamber. The CID experiments were performed by isolating the proton-bound heterodimeric anions with the first quadrupole $\left(\mathrm{MS}^{1}\right)$ with a peak width of $\sim 1.0-1.2$ (instrument parameter), adjusted to maximize ion signal while still maintaining sufficient resolution. The isolated ions were allowed to undergo collisions with argon atoms leaked into the collision chamber at a pressure of around 0.5 mTorr. The dissociation product ions were analyzed with the

\begin{tabular}{|c|c|c|c|c|}
\hline & & $\Delta_{\text {acid }} H^{a}$ & $\Delta_{\text {acid }} G^{a}$ & $\Delta_{\text {acid }} S^{b}$ \\
\hline Reference acid & Abbreviation & (kcal/mol) & (kcal/mol) & (cal/mol K) \\
\hline $\mathrm{C}_{3} \mathrm{~F}_{7} \mathrm{CO}_{2} \mathrm{H}$ & HFBAH & $321.9 \pm 2.2$ & $314.9 \pm 2.0$ & 23.5 \\
\hline $\mathrm{F}_{3} \mathrm{CCO}_{2} \mathrm{H}$ & TFAH & $323.8 \pm 2.9$ & $317.4 \pm 2.0$ & 21.5 \\
\hline $\mathrm{Br}_{2} \mathrm{CHCO}_{2} \mathrm{H}$ & DBAH & $328.3 \pm 2.2$ & $321.3 \pm 2.0$ & 23.5 \\
\hline $\mathrm{Cl}_{2} \mathrm{CHCO}_{2} \mathrm{H}$ & DCAH & $328.4 \pm 2.1$ & $321.9 \pm 2.0$ & 21.8 \\
\hline $\mathrm{F}_{2} \mathrm{CHCO}_{2} \mathrm{H}$ & DFAH & $331.0 \pm 2.2$ & $323.8 \pm 2.0$ & 24.2 \\
\hline $\mathrm{BrCH}_{2} \mathrm{CO}_{2} \mathrm{H}$ & MBAH & $334.8 \pm 2.3$ & $328.2 \pm 2.0$ & 22.1 \\
\hline $\mathrm{ClCH}_{2} \mathrm{CO}_{2} \mathrm{H}$ & MCAH & $336.5 \pm 2.2$ & $329.0 \pm 2.0$ & 25.2 \\
\hline
\end{tabular}
third quadrupole $\left(\mathrm{MS}^{2}\right)$ with a peak width of $\sim 1.2-1.5$.

Table 1. Thermochemical quantities of the reference acids used in this work

a Obtained from the NIST Chemistry WebBook [91].

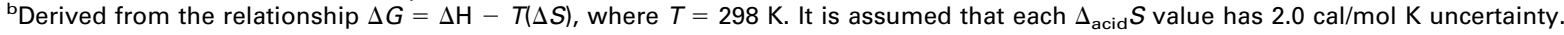


The CID spectra were initially recorded at several collision energies with the $\mathrm{m} / \mathrm{z}$ range wide enough to cover all possible secondary fragments. The CID product ion intensities were measured by setting the instrument in the selected reaction monitoring (SRM) mode in which the scan was focused on selected product ions. All fragment ions resulting from the isolated protonbound dimer ions were recorded in a single data acquisition process, lasting typically for $\sim 5 \mathrm{~min}$. Each acquisition was repeated three times in one day. Multiple measurements were performed on different days and the results were repeatable with a relative uncertainty of around $\pm 5 \%$. The CID experiments were performed at four different collision energies, corresponding to the center-of-mass energies $\left(E_{\mathrm{cm}}\right)$ of 1.0, 1.5, 2.0 , and $2.5 \mathrm{eV}$, respectively. The center-of-mass energy was calculated using the equation: $E_{\mathrm{cm}}=E_{\text {lab }}[\mathrm{m} /(\mathrm{M}+$ $\mathrm{m})]$, where $E_{\mathrm{lab}}$ is the collision energy in laboratory frame, $m$ is the mass of argon, and $M$ is the mass of the proton-bound dimer ion.

Stock solutions $\left(\sim 10^{-3} \mathrm{M}\right)$ of all peptides and reference acids were made up in HPLC-grade methanol and water with a 50:50 (vol:vol) ratio. Stock solutions of a peptide and a reference acid were mixed in appropriate volumes and then diluted with methanol and water (50:50) to achieve a final concentration of $10^{-4}-10^{-5} \mathrm{M}$ to be used as the sample solution. The sample solution was introduced into the source of the mass spectrometer by an infusion pump at a flow rate of $10 \mu \mathrm{L} / \mathrm{min}$.

\section{Peptide Synthesis}

All peptides were synthesized in our laboratory using the standard method of solid-phase peptide synthesis [77-79]. The apparatus consists of glass peptide synthesis vessels (Kemtech America, Inc., Whittier, CA, USA) mounted on a mechanical agitator (Wrist-Action Shaker; Burrell Scientific, Pittsburgh, PA, USA). The Rink amide resin was used as the solid support to yield the amide C-terminus. The general protocols of peptide synthesis involve (1) Activate and couple the fmocprotected amino acid onto the solid resin; (2) remove the fmoc protecting group and couple the second fmocamino acid to the $N$-terminus of the one linked to the resin; (3) repeat the coupling/decoupling processes until the peptide chain reaches the desired length; (4) cleave the peptide from the resin. The resulting crude peptide was isolated by precipitation in cold ether and/or by liquid extraction, and was dried by lyophilization. The peptide obtained was sufficiently pure for mass spectrometry measurements. The sequence of the peptide was confirmed by using tandem mass spectrometry experiments. All chemicals used in the peptide synthesis, including the Rink amide resin, fmoc-cysteine, and fmoc-glycine, were purchased from either Sigma-Aldrich Chemical Co. (Milwaukee, WI, USA) or ChemPep Inc. (Miami, FL, USA) and were used without further purification.

\section{Computational Method}

The conformations of the neutral and deprotonated peptides were examined using the simulated annealing process, followed by geometry refinements at the AM1 level [80], and finally energy calculations using density functional theory (DFT) [81-84]. The simulated annealing was performed using the Tripos force field implemented in the SYBYL 7.2 package of programs (Tripos, Inc., St. Louis, MO, USA). The starting structures of all peptides were ideal $\alpha$-helices. The general procedure involved heating the system to $500 \mathrm{~K}$ for $1500 \mathrm{fs}$, followed by annealing to $50 \mathrm{~K}$ for $1600 \mathrm{fs}$ for 100 cycles per simulation. Structures were saved at regular intervals (50 fs) throughout the simulations. Upon completion, 10 low-energy conformations for each peptide were selected for further geometry optimization using the AM1 semi-empirical method implemented in the Gaussian W03 suite of programs [85]. Vibrational frequencies were also calculated using AM1 to yield the zero-point energies and the thermal corrections to the enthalpy at $298 \mathrm{~K}$. True energy minima were confirmed by the absence of imaginary frequencies from the set of obtained frequencies. Following geometry optimization, single point energies were calculated at the B3LYP/6-31+G(d) level to yield the energetic information of the selected conformations.

\section{Results}

Our preliminary studies suggested that the gas-phase acidities of the four peptides $(\mathrm{AH}), \mathrm{CG}_{3} \mathrm{H}, \mathrm{CG}_{4} \mathrm{H}$, $\mathrm{G}_{3} \mathrm{CH}$, and $\mathrm{G}_{4} \mathrm{CH}$ (Scheme 1), are comparable to those of halogenated carboxylic acids. We selected seven structural similar halogenated acetic acid derivatives as the reference acids $\left(\mathrm{A}_{\mathrm{i}} \mathrm{H}\right): \mathrm{CF}_{3} \mathrm{CF}_{2} \mathrm{CF}_{2} \mathrm{CO}_{2} \mathrm{H}$ (heptafluoro buteric acid, $\mathrm{HFBAH}), \mathrm{F}_{3} \mathrm{CCO}_{2} \mathrm{H}$ (trifluoroacetic acid, TFAH), $\mathrm{Br}_{2} \mathrm{CHCO}_{2} \mathrm{H}$ (dibromoacetic acid, DBAH), $\mathrm{Cl}_{2} \mathrm{CHCO}_{2} \mathrm{H}$ (dichloroacetic acid, DCAH), $\mathrm{F}_{2} \mathrm{CHCO}_{2} \mathrm{H}$ (difluoroacetic acid, DFAH), $\mathrm{BrCH}_{2} \mathrm{CO}_{2} \mathrm{H}$ (monobromoacetic acid, $\mathrm{MBAH}$ ), and $\mathrm{ClCH}_{2} \mathrm{CO}_{2} \mathrm{H}$ (monochloroacetic acid, MCAH). The thermochemical properties of these compounds, $\Delta_{\text {acid }} H, \Delta_{\text {acid }} G$, and $\Delta_{\text {acid }} S$, are given in Table 1 . We first examined the relative acidities of the peptides compared to these reference acids by using CID bracketing experiments. Proton-bound heterodimeric anions, $\left[\mathrm{A} \cdot \mathrm{H} \cdot \mathrm{A}_{\mathrm{i}}\right]^{-}$, were generated under ESI conditions and the CID experiments were performed at $1.5 \mathrm{eV}\left(E_{\mathrm{cm}}\right)$ collision energy and the CID spectra were recorded. All CID spectra showed two major product anions, $\mathrm{A}^{-}$and $\mathrm{A}_{\mathrm{i}}^{-}$. The relative intensities of the two anions indicate the relative acidities of $\mathrm{AH}$ and $\mathrm{A}_{\mathrm{i}} \mathrm{H}$. For example, if the ion intensity of $\mathrm{A}^{-}$is stronger than that of $\mathrm{A}_{\mathrm{i}}^{-}$, then the gas-phase acidity of $\mathrm{AH}$ is greater than that of $\mathrm{A}_{\mathrm{i}} \mathrm{H}$. Selected CID spectra are shown in Figure 1. The spectra reveal that the ion intensity of $\mathrm{CG}_{3}^{-}$is slightly higher than that of $\mathrm{DCA}^{-}$, and lower than that of $\mathrm{DBA}^{-}$, suggesting that the acidity of $\mathrm{CG}_{3} \mathrm{H}$ is between those of 

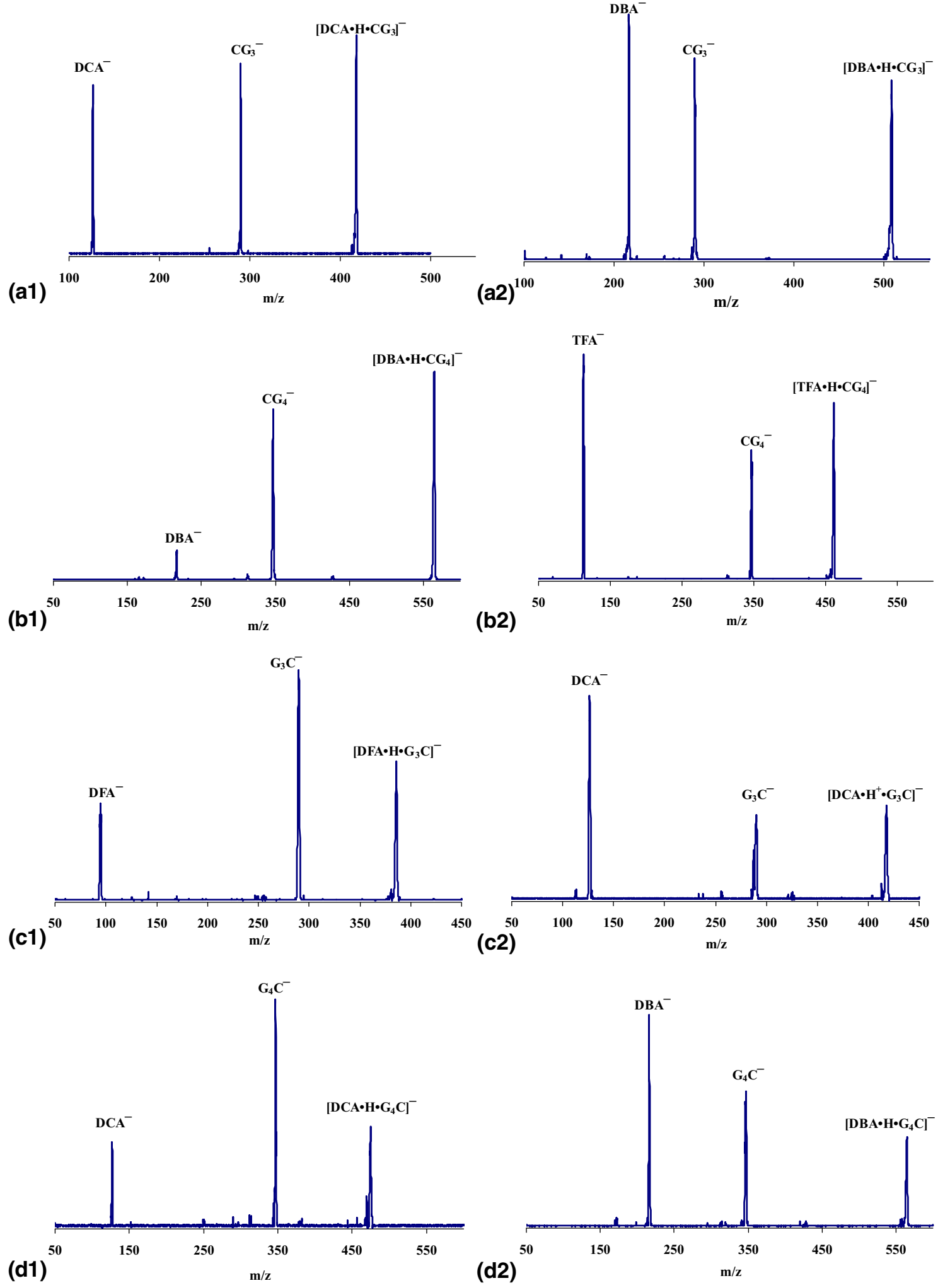

Figure 1. CID spectra obtained at $1.5 \mathrm{eV}\left(E_{\mathrm{cm}}\right)$ for the proton bound heterodimer anions of (a1) $\left[\mathrm{DCA} \cdot \mathrm{H} \cdot \mathrm{CG}_{3}\right]^{-},(\mathbf{a} 2)\left[\mathrm{DBA} \cdot \mathrm{H} \cdot \mathrm{CG}_{3}\right]^{-}$, (b1) $\left[\mathrm{DBA} \cdot \mathrm{H} \cdot \mathrm{CG}_{4}\right]^{-}$, (b2) $\left[\mathrm{TFA} \cdot \mathrm{H} \cdot \mathrm{CG}_{4}\right]^{-}$, (c1) $\left[\mathrm{DFA} \cdot \mathrm{H} \cdot \mathrm{G}_{3} \mathrm{C}\right]^{-}$, (c2) $\left[D C A \cdot H \cdot G_{3} C\right]^{-},($d1 $)\left[D C A \cdot H \cdot G_{4} C\right]^{-},(d 2)\left[D B A \cdot H \cdot G_{4} C\right]^{-}$.

these two reference acids: DCAH $<\mathrm{CG}_{3} \mathrm{H}<\mathrm{DBAH}$. Similar comparisons suggested the relative acidities of other peptides: DBAH $<\mathrm{CG}_{4} \mathrm{H}<\mathrm{TFAH}, \mathrm{DFAH}<$
$\mathrm{G}_{3} \mathrm{CH}<\mathrm{DCAH}$, and $\mathrm{DCAH}<\mathrm{G}_{4} \mathrm{CH}<\mathrm{DBAH}$. The results also show that the two $\mathrm{N}$-terminal cysteine peptides are more acidic than the corresponding C- 
terminal peptides. The order of the acidities of the four peptides is: $\mathrm{CG}_{4} \mathrm{H}>\mathrm{CG}_{3} \mathrm{H} \approx \mathrm{G}_{4} \mathrm{CH}>\mathrm{G}_{3} \mathrm{CH}$.

\section{Gas-Phase Acidity Measurements}

To determine the quantitative values of the gas-phase acidities of the peptides, additional experiments were performed. The CID product ion intensities were recorded at four collision energies $\left(E_{\mathrm{cm}}\right), 1.0,1.5,2.0$, and $2.5 \mathrm{eV}$. At higher energies (2.0 and $2.5 \mathrm{eV}$ ), about $5 \%$ of the peptide ion fragments further by losing $\mathrm{H}_{2} \mathrm{~S}$, and about $2 \%$ to $10 \%$ of the ionic reference acids yield smaller ions by losing the $\mathrm{CO}_{2}$ group. All secondary fragments were included in the data analysis. For the chloro- and bromo-substituted reference acids, the most abundant isotopic peaks of the proton-bound heterodimers were selected as the precursor ions for the CID experiments. These ions should be isotopically pure.

The natural logarithms of the CID product ion branching ratios, $\ln \left(\left[\mathrm{A}^{-}\right] /\left[\mathrm{A}_{\mathrm{i}}^{-}\right]\right)$, measured at four collision energies for all the reference compounds are shown in Table 2. A plot of $\ln \left(\left[\mathrm{A}^{-}\right] /\left[\mathrm{A}_{\mathrm{i}}^{-}\right]\right)$measured at the same collision energy verses the values of $\Delta_{\text {acid }} H_{i}-$ $\Delta_{\text {acid }} H_{\text {Avg }}$ for all of the reference compounds would give a straight line with the slope of $1 / R T_{\text {eff }}(X)$ and intercept of $-\left[\left(\Delta_{\text {acid }} H-\Delta_{\text {acid }} H_{\text {avg }}\right) / R T_{\text {eff }}-\Delta(\Delta S) / R\right]$ $(\mathrm{Y})$, eq 4 . The plots of $\ln \left(\left[\mathrm{CG}_{3}^{-}\right] /\left[\mathrm{A}_{\mathrm{i}}^{-}\right]\right), \ln \left(\left[\mathrm{CG}_{4}^{-}\right] /\left[\mathrm{A}_{\mathrm{i}}^{-}\right]\right)$, $\ln \left(\left[\mathrm{G}_{3} \mathrm{C}^{-}\right] /\left[\mathrm{A}_{\mathrm{i}}^{-}\right]\right)$and $\ln \left(\left[\mathrm{G}_{4} \mathrm{C}^{-}\right] /\left[\mathrm{A}_{\mathrm{i}}^{-}\right]\right)$against $\Delta_{\text {acid }} H_{\mathrm{i}}-$ $\Delta_{\text {acid }} H_{\text {avg }}$ at four collision energies are shown in Figure 2 (a1), (b1), (c1), and (d1). The values of the slopes and intercepts resulted from weighted linear regression for the four peptide systems are summarized in Table 3. The corresponding effective temperatures $\left(T_{\text {eff }}\right)$ are also shown in Table 3. For the systems of $\mathrm{CG}_{3,4} \mathrm{H}$ and $\mathrm{G}_{4} \mathrm{CH}$, the effective temperatures increase with the increase of the collision energy. For the system of $\mathrm{G}_{3} \mathrm{CH}$, the effective temperatures do not follow the expected trend. The reason for the unexpected behavior is not clear at this point.

The values of the intercept at different collision energies obtained above, $Y$, were further plotted against the corresponding slopes, $X$. The plots for the four peptide systems are shown in Figure 2 (a2), (b2), (c2), and $(\mathrm{d} 2)$. These plots were then used to extract the values of $\left[\Delta_{\text {acid }} H-\Delta_{\text {acid }} H_{\text {avg }}\right]$ from the slope and the values of $[\Delta(\Delta S) / R]$ from the intercept. The slopes and intercepts resulted from weighted linear regression are summarized in Table 4. The corresponding entropy terms, $\Delta(\Delta S)$, are also shown in Table 4 . For each peptide system, the magnitude of $\Delta_{\text {acid }} H_{\text {avg }}$ is known (Table 2). The deprotonation enthalpy $\left(\Delta_{\text {acid }} H\right)$ of a peptide was obtained by combining the value of $\Delta_{\text {acid }} H_{\text {avg }}$ and the slope. The results for the four peptides are summarized in Table 5.

The uncertainties were calculated by weighted orthogonal distance regression (ODR) using the ODRPACK suite of programs [86]. An example for the $\mathrm{CG}_{3} \mathrm{H}$ system is given here. For each of the plots of $\ln \left(\left[\mathrm{A}^{-}\right] /\right.$ $\left.\left[\mathrm{A}_{\mathrm{i}}^{-}\right]\right)$against $\Delta_{\text {acid }} H_{\mathrm{i}}-\Delta_{\text {acid }} H_{\mathrm{Avg}}$, the uncertainty used in all $\mathrm{x}$-axis values is $2.2 \mathrm{kcal} / \mathrm{mol}$, and in all $\mathrm{y}$-axis values is 0.05 . The yielding uncertainties (with $95 \%$

Table 2. Values of $\ln \left(\left[\mathrm{A}^{-}\right] /\left[\mathrm{A}_{\mathrm{i}}^{-}\right]\right)$measured at four collisions energies $\left(E_{\mathrm{cm}}\right)$ with various reference acids, and average enthalpies and entropies of the reference acids

\begin{tabular}{|c|c|c|c|c|c|c|c|}
\hline \multirow[b]{2}{*}{ Peptide } & \multirow[b]{2}{*}{ Reference Acid } & \multirow[b]{2}{*}{$\Delta_{\text {acid }} H_{\text {avg }}{ }^{a} \mathrm{kcal} / \mathrm{mol}$} & \multirow[b]{2}{*}{$\Delta_{\text {acid }} S_{\text {avg }}{ }^{\mathrm{b}} \mathrm{kcal} / \mathrm{mol} \mathrm{K}$} & \multicolumn{4}{|c|}{$E_{\mathrm{cm}}{ }^{\mathrm{c}}$} \\
\hline & & & & $1.0 \mathrm{eV}$ & $1.5 \mathrm{eV}$ & $2 \mathrm{eV}$ & $2.5 \mathrm{eV}$ \\
\hline \multirow[t]{5}{*}{$\mathrm{CG}_{3} \mathrm{H}$} & HFBAH & 326.7 & 22.9 & -3.882 & -3.905 & -3.933 & -3.903 \\
\hline & TFAH & & & -1.844 & -1.737 & -1.638 & -1.510 \\
\hline & DBAH & & & 0.562 & 0.236 & 0.027 & -0.123 \\
\hline & $\mathrm{DCAH}$ & & & 0.319 & 0.269 & 0.249 & 0.279 \\
\hline & DFAH & & & 1.946 & 1.754 & 1.724 & 1.751 \\
\hline \multirow[t]{5}{*}{$\mathrm{CG}_{4} \mathrm{H}$} & HFBAH & 326.7 & 22.9 & -2.789 & -2.911 & -3.009 & -3.012 \\
\hline & TFAH & & & -0.532 & -0.800 & -0.853 & -0.815 \\
\hline & DBAH & & & 1.873 & 1.329 & 0.879 & 0.584 \\
\hline & DCAH & & & 1.993 & 1.500 & 1.274 & 1.122 \\
\hline & DFAH & & & 3.935 & 3.254 & 3.017 & 3.142 \\
\hline \multirow[t]{5}{*}{$\mathrm{G}_{3} \mathrm{CH}$} & DBAH & 331.8 & 23.3 & -0.995 & -1.246 & -1.440 & -1.585 \\
\hline & DCAH & & & -1.519 & -1.585 & -1.470 & -1.474 \\
\hline & DFAH & & & 0.297 & 0.144 & 0.191 & 0.248 \\
\hline & MBAH & & & 1.038 & 1.030 & 0.994 & 0.924 \\
\hline & MCAH & & & 2.722 & 2.860 & 2.918 & 2.951 \\
\hline \multirow{6}{*}{$\mathrm{G}_{4} \mathrm{CH}$} & HFBAH & 328.9 & 22.5 & -3.665 & -3.676 & -3.749 & -3.763 \\
\hline & TFAH & & & -2.346 & -2.332 & -2.195 & -2.052 \\
\hline & DBAH & & & -0.084 & -0.326 & -0.582 & -0.756 \\
\hline & DCAH & & & 0.028 & -0.139 & -0.177 & -0.185 \\
\hline & MBAH & & & 4.028 & 3.838 & 3.584 & 3.297 \\
\hline & MCAH & & & 5.435 & 5.213 & 4.985 & 4.815 \\
\hline
\end{tabular}

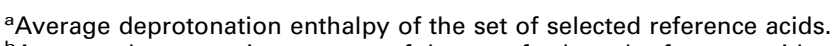

${ }^{\mathrm{b}}$ Average deprotonation entropy of the set of selected reference acids.

'The data include $\pm 5 \%$ of uncertainty. 

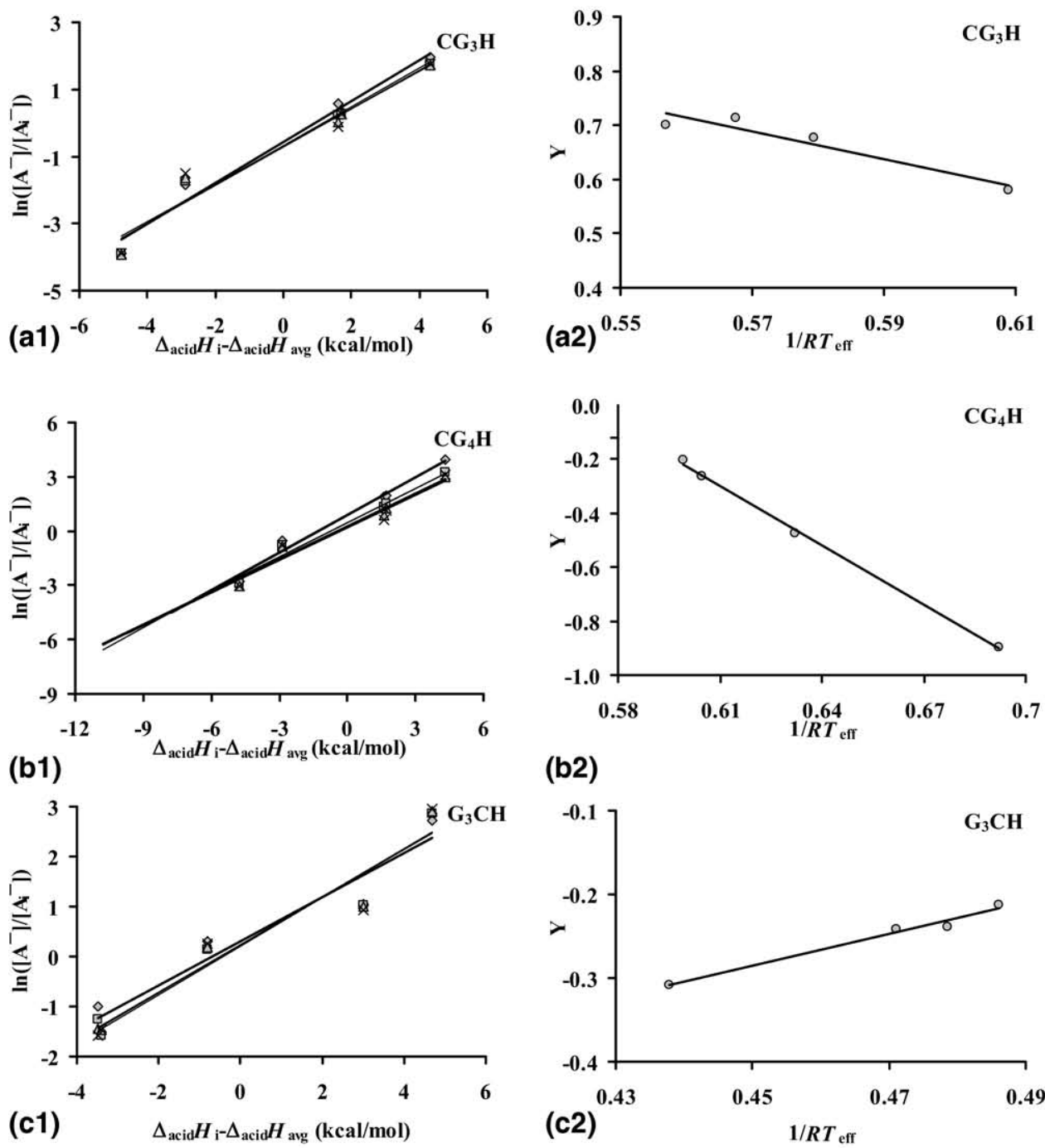

(b2)
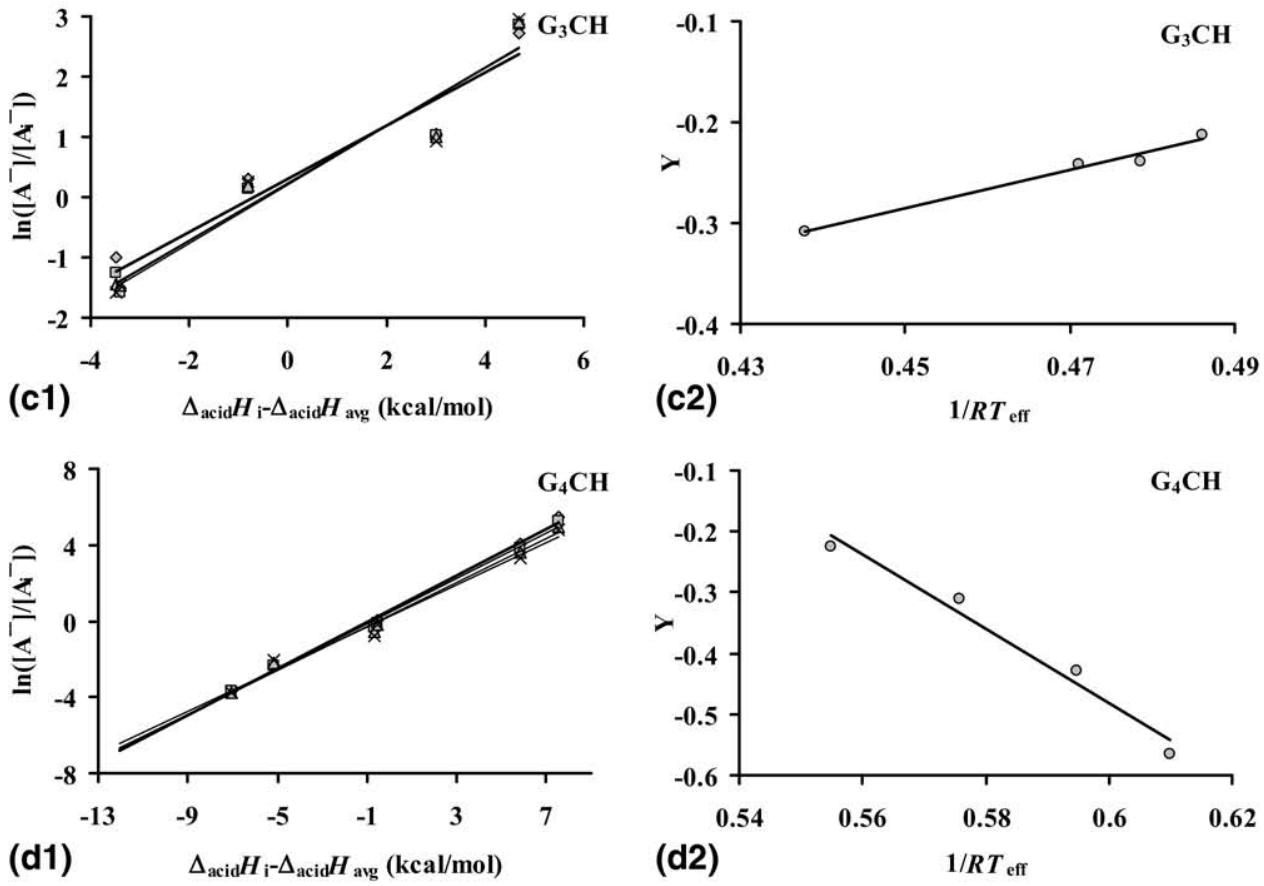

Figure 2. (1) Plots of $\ln \left(\left[\mathrm{A}^{-}\right] /\left[\mathrm{A}_{\mathrm{i}}^{-}\right]\right)$versus $\Delta_{\text {acid }} H_{\mathrm{i}}-\Delta_{\text {acid }} H_{\text {avg }}$ from the dissociation of $\left[\mathrm{A}_{\mathrm{i}} \cdot \mathrm{H} \cdot \mathrm{A}\right]^{-}$at four collision energies $\left(E_{\mathrm{cm}}\right), 1.0,1.5,2.0$, and $2.5 \mathrm{eV}$. The darker line corresponds to the lowest energy in each set of the data. (2) Plots of $\mathrm{y}=\left(\Delta_{\text {acid }} H-\Delta_{\text {acid }} H_{\text {avg }}\right) / R T_{\text {eff }}-\Delta(\Delta S) / R$ versus $1 / R T_{\text {eff }}$.

confidence) in slope $(\mathrm{X})$ and in intercepts $(\mathrm{Y})$ are shown in Table 3. The corresponding uncertainties were carried into the plot of $Y$ against $X$. The resulting uncertainty in the slope $\left(\Delta_{\text {acid }} H-\Delta_{\text {acid }} H_{\text {avg }}\right)$ is 0.69 and in the intercept $(\Delta(\Delta S) / R)$ is 0.40 . Combined with the 1.8 $\mathrm{kcal} / \mathrm{mol}$ uncertainty estimated for $\Delta_{\text {acid }} H_{\text {avg }}$ (Experimental), the uncertainty for $\Delta_{\text {acid }} H$ would be $2.5 \mathrm{kcal} /$ $\mathrm{mol}$. The results of detailed uncertainty analysis for the
$\mathrm{CG}_{3} \mathrm{H}$ system are given in the supplemental material, which can be found in the electronic version of this article. It should be pointed out that the uncertainties obtained from the kinetic measurements are relative values. They do not include the absolute error in the overall calibration of the acidity scale of the references.

The entropy term is used to calculate the deprotonation entropy of each peptide by using the equation, 
Table 3. Results of linear regression according to eq 4, the first set of the thermokinetic plots ${ }^{\mathrm{a}}$

\begin{tabular}{|c|c|c|c|c|c|}
\hline & $E_{\mathrm{cm}}, \mathrm{eV}$ & 1.0 & 1.5 & 2.0 & 2.5 \\
\hline \multirow[t]{3}{*}{$\mathrm{CG}_{3} \mathrm{H}$} & $x$ & $0.61 \pm 0.05$ & $0.58 \pm 0.06$ & $0.57 \pm 0.07$ & $0.56 \pm 0.08$ \\
\hline & $Y$ & $-0.58 \pm 0.17$ & $-0.68 \pm 0.20$ & $-0.71 \pm 0.23$ & $-0.70 \pm 0.26$ \\
\hline & Z & $826 \pm 68$ & $868 \pm 90$ & $886 \pm 109$ & $904 \pm 129$ \\
\hline \multirow[t]{3}{*}{$\mathrm{CG}_{4} \mathrm{H}$} & $x$ & $0.69 \pm 0.05$ & $0.63 \pm 0.05$ & $0.6 \pm 0.06$ & $0.6 \pm 0.08$ \\
\hline & $Y$ & $0.89 \pm 0.18$ & $0.47 \pm 0.18$ & $0.26 \pm 0.22$ & $0.2 \pm 0.27$ \\
\hline & Z & $727 \pm 53$ & $796 \pm 63$ & $832 \pm 83$ & $840 \pm 112$ \\
\hline \multirow[t]{3}{*}{$\mathrm{G}_{3} \mathrm{CH}$} & $x$ & $0.44 \pm 0.07$ & $0.47 \pm 0.06$ & $0.48 \pm 0.07$ & $0.49 \pm 0.08$ \\
\hline & $\mathrm{Y}$ & $-0.31 \pm 0.22$ & $-0.24 \pm 0.22$ & $-0.24 \pm 0.23$ & $-0.21 \pm 0.25$ \\
\hline & Z & $1149 \pm 183$ & $1068 \pm 136$ & $1051 \pm 153$ & $1035 \pm 169$ \\
\hline \multirow{3}{*}{$\mathrm{G}_{4} \mathrm{CH}$} & $x$ & $0.61 \pm 0.02$ & $0.59 \pm 0.02$ & $0.58 \pm 0.03$ & $0.56 \pm 0.04$ \\
\hline & $Y$ & $0.57 \pm 0.10$ & $0.43 \pm 0.13$ & $0.31 \pm 0.16$ & $0.23 \pm 0.20$ \\
\hline & Z & $825 \pm 27$ & $846 \pm 29$ & $874 \pm 45$ & $907 \pm 65$ \\
\hline
\end{tabular}

$\mathrm{X}=1 / R T_{\text {eff }} ; \mathrm{Y}=-\left[\left(\Delta_{\text {acid }} H-\Delta_{\text {acid }} H_{\text {avg }}\right) / R T_{\text {eff }}-\Delta(\Delta S) / R\right] ; \mathrm{Z}=T_{\text {eff }} \mathrm{K}$.

aThe uncertainties were calculated by weight orthogonal distance regression (ODR) using the ODRPAC suite of program [86].

$\Delta_{\text {acid }} S=\Delta(\Delta S)+\Delta_{\text {acid }} S_{\text {i }}$, where $\Delta_{\text {acid }} S_{\mathrm{i}}$ is estimated using the average deprotonation entropy of the reference acids ( $\Delta_{\text {acid }} S_{\text {avg }}$, Table 2$)$. The resulting deprotonation entropies for the four peptides are listed in Table 5. With $\Delta_{\text {acid }} H$ and $\Delta_{\text {acid }} S$ available, we can derive the gas-phase acidities $\left(\Delta_{\text {acid }} G\right)$ of the peptide by using the relationship shown in eq 5 . The resulting gas-phase acidities for the four peptides are given in Table 5. We assigned the same levels of uncertainties to $\Delta_{\text {acid }} G$ as those for $\Delta_{\text {acid }} H$. The quantitative measurements suggest that $\mathrm{CG}_{3} \mathrm{H}$ is a stronger acid than its analogue, $\mathrm{G}_{3} \mathrm{CH}$, by about $9 \mathrm{kcal} / \mathrm{mol}$, and $\mathrm{CG}_{4} \mathrm{H}$ is a stronger acid than $\mathrm{G}_{4} \mathrm{CH}$ by about $3 \mathrm{kcal} / \mathrm{mol}$. The two peptides, $\mathrm{CG}_{3} \mathrm{H}$ and $\mathrm{G}_{4} \mathrm{CH}$, have similar acidities.

\section{Computational Results}

Conformations of the neutral and deprotonated peptides were calculated using the simulated annealing procedure. For each of the peptide species, the initial input conformation was a helix. Upon completion of the annealing process, around 25 lowest energy conformations were visually evaluated. Among them, 10 conformations were selected as the initial geometries for further optimization using the AM1 method. The optimized geometries were then subjected to single point energy calculations to yield energetic information. The procedure is fast and gives reasonable relative energies for the different conformations. Representative lowestenergy conformations of the four deprotonated peptides are shown in Figure 3. There are several (however,

Table 4. Results of linear regression according to eq 4, the second set of the thermokinetic plots ${ }^{a}$

\begin{tabular}{lrrr}
\hline & $\Delta_{\text {acid }} H-\Delta_{\text {acid }} H_{\text {avg }}$ & \multicolumn{1}{c}{$\Delta(\Delta S) / R$} & $\Delta(\Delta S)(\mathrm{cal} / \mathrm{mol} \mathrm{K})$ \\
\hline \hline $\mathrm{CG}_{3} \mathrm{H}$ & $-2.83 \pm 0.69$ & $2.31 \pm 0.40$ & $-4.57 \pm 0.79$ \\
$\mathrm{CG}_{4} \mathrm{H}$ & $-7.46 \pm 0.49$ & $4.25 \pm 0.31$ & $-8.45 \pm 0.62$ \\
$\mathrm{G}_{3} \mathrm{CH}$ & $1.99 \pm 0.26$ & $-1.19 \pm 0.12$ & $2.40 \pm 0.24$ \\
$\mathrm{G}_{4} \mathrm{CH}$ & $-7.05 \pm 1.00$ & $3.74 \pm 0.58$ & $-7.40 \pm 1.15$ \\
\hline
\end{tabular}

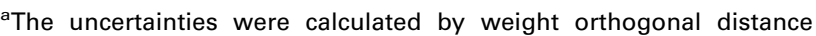
regression (ODR) using the ODRPAC suite of program [86]. there could be many) possible low-energy conformations associated with each neutral peptide. The shapes of the conformations are mainly random coils. Each deprotonated peptide also adopts several possible lowenergy conformations. The conformations of the deprotonated peptides are relatively compact compared with those of the neutral ones. The shapes for $\mathrm{G}_{3,4} \mathrm{C}^{-}$are mainly random coils with the negatively charged sulfur atom (thiolate anion) solvated by nearby $\mathrm{N}-\mathrm{H}$ groups. The low-energy conformations of $\mathrm{CG}_{3,4}{ }^{-}$exhibit two different shapes, the random coils and the stretched helical loops. In the random coils, the thiolate anion is solvated by nearby N-H groups. In the helical loops, the thiolate anion resides next to the axis of the helix.

\section{Discussion}

Polyglycine-based peptides are known to mainly adopt random coils in the gas-phase [60]. Longer peptides are expected to be more acidic than the corresponding short ones, since longer peptides can stabilize the negative charges resulting from deprotonation more effectively through internal solvation in the forms of hydrogen bonding interactions and charge-dipole interactions. A comparable trend was found in the basicities of polyglycine peptides. The basicities increased as the peptide chain length increased. This was mainly because of the stabilization of the positive charge, the proton, through

Table 5. Thermochemical quantities of the peptides obtained from this work

\begin{tabular}{lccc}
\hline Peptide & $\begin{array}{c}\Delta_{\text {acid }} H \\
(\mathrm{kcal} / \mathrm{mol})\end{array}$ & $\begin{array}{c}\Delta S^{\mathrm{a}} \\
(\mathrm{cal} / \mathrm{mol} \mathrm{K})\end{array}$ & $\begin{array}{c}\Delta_{\text {acid }} G^{\mathrm{b}} \\
(\mathrm{kcal} / \mathrm{mol})\end{array}$ \\
\hline \hline $\mathrm{CG}_{3} \mathrm{H}$ & $323.9 \pm 2.5$ & $18.3 \pm 2.0$ & $318.4 \pm 2.5$ \\
$\mathrm{CG}_{4} \mathrm{H}$ & $319.2 \pm 2.3$ & $14.4 \pm 2.0$ & $314.9 \pm 2.3$ \\
$\mathrm{G}_{3} \mathrm{CH}$ & $333.8 \pm 2.1$ & $21.0 \pm 2.0$ & $327.5 \pm 2.1$ \\
$\mathrm{G}_{4} \mathrm{CH}$ & $321.9 \pm 2.8$ & $15.1 \pm 2.0$ & $317.4 \pm 2.8$ \\
\hline
\end{tabular}

${ }^{\text {a} C a l c u l a t e d ~ u s i n g ~ t h e ~ e q u a t i o n ~} \Delta_{\text {acid }} S=\Delta(\Delta S)+\Delta_{\text {acid }} S_{\text {avg, }}$, where $\Delta(\Delta S)$ is the entropy term (Table 4 ) and $\Delta_{\text {acid }} S_{\text {avg }}$ is the average deprotonation entropy of the reference acids (Table 2).

${ }^{\mathrm{b}}$ Calculated using eq 5 , where $T=298 \mathrm{~K}$. 


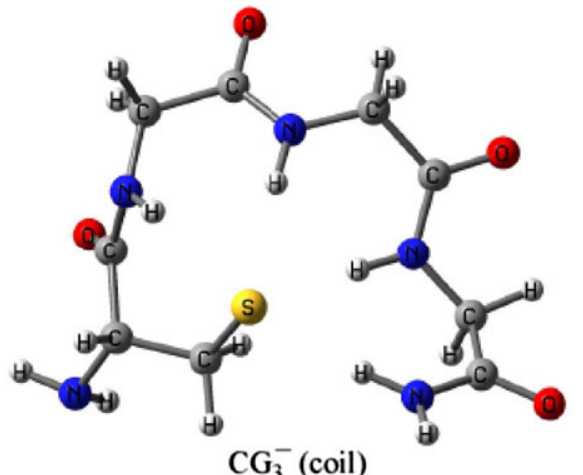

$\mathrm{CG}_{3}^{-}$(coil)
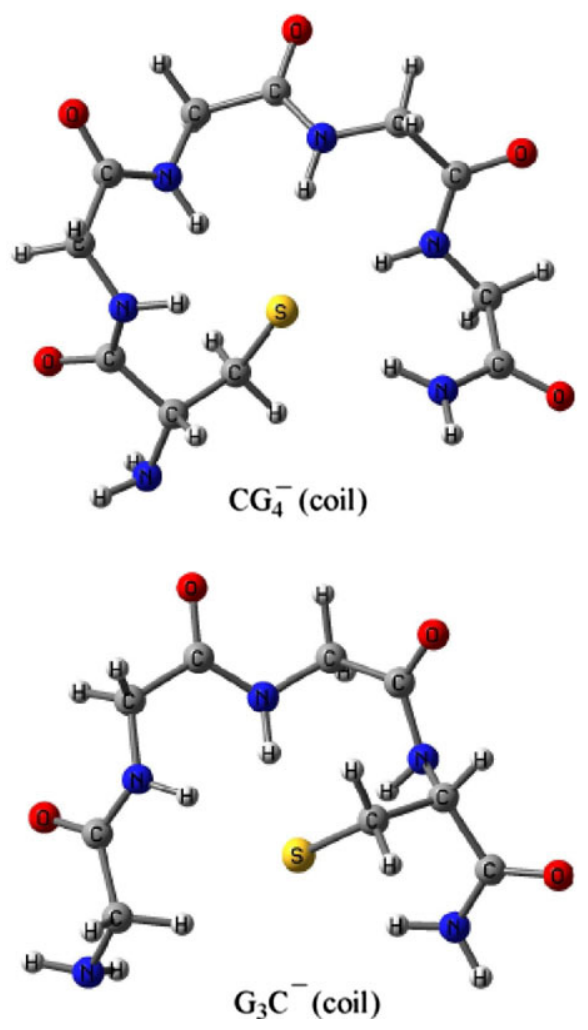

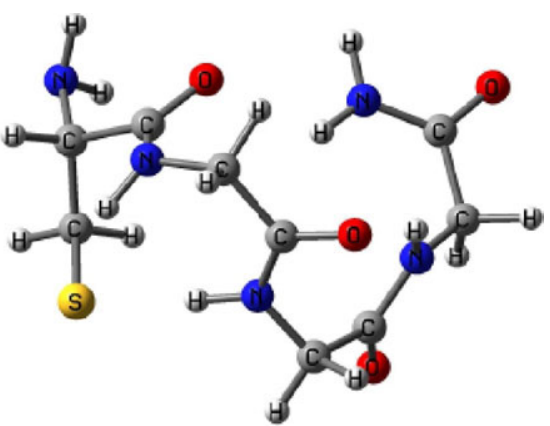

$\mathrm{CG}_{3}^{-}$(helix)

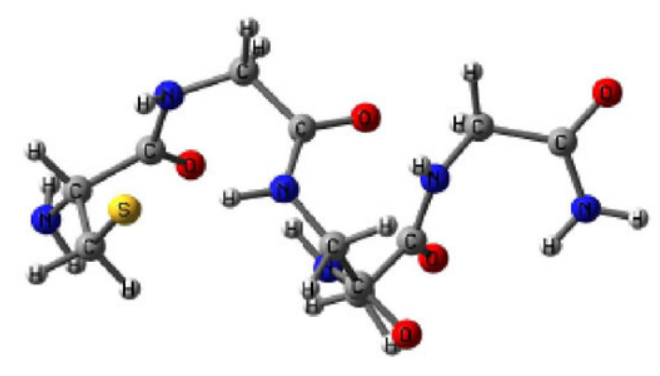

$\mathrm{CG}_{4}^{-}$(helix)

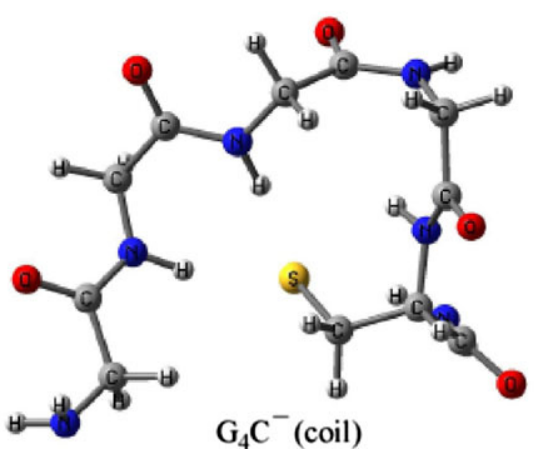

Figure 3. Representative conformations for the deprotonated peptides obtained from the AM1// simulated annealing procedure.

multiple hydrogen bonding interactions $[44,87,88]$. The experimental results from this work clearly show that the two longer peptides, $\mathrm{CG}_{4} \mathrm{H}$ and $\mathrm{G}_{4} \mathrm{CH}$, are more acidic than the corresponding short ones, $\mathrm{CG}_{3} \mathrm{H}$ and $\mathrm{G}_{3} \mathrm{CH}$. What is interesting is that the N-terminal cysteine polyglycine peptides, $\mathrm{CG}_{3} \mathrm{H}$ and $\mathrm{CG}_{4} \mathrm{H}$, are also significantly more acidic than the corresponding $\mathrm{C}$ terminal cysteine analogues, $\mathrm{G}_{3} \mathrm{CH}$ and $\mathrm{G}_{4} \mathrm{CH}$, by 9 and $3 \mathrm{kcal} / \mathrm{mol}$, respectively. This implies that the thiolate anion $\left(\mathrm{S}^{-}\right)$in $\mathrm{CG}_{3,4}{ }^{-}$is stabilized more than that in $\mathrm{G}_{3,4} \mathrm{C}^{-}$.

This similar behavior has been observed in the cysteine-polyalanine peptides [57]. The N-cysteine peptides, $\mathrm{CA}_{3} \mathrm{H}$ and $\mathrm{CA}_{4} \mathrm{H}$, are more acidic than the Ccysteine ones, $\mathrm{A}_{3} \mathrm{CH}$ and $\mathrm{A}_{4} \mathrm{CH}$, by 10 and $5 \mathrm{kcal} / \mathrm{mol}$, respectively. Computational studies showed that the deprotonated C-cysteine peptides, $\mathrm{A}_{3,4} \mathrm{C}^{-}$, adopted random coils with the thiolate anion stabilized by hydrogen bonding interactions with nearby $\mathrm{N}-\mathrm{H}$ groups. While the deprotonated N-cysteine peptides, $\mathrm{CA}_{3,4}{ }^{-}$, exist as partial helices with the negatively charged sulfur atom pointing to the axis of the helix loop. In this case, the thiolate anion may be largely stabilized by the interaction with the helix macrodipole in addition to the possible hydrogen bonding interactions. The helix macrodipole is an intrinsic property of helical peptides arising from the alignment of the polar peptide bonds, which in turn creates a dipolar electrostatic field with a partial positive charge at the $\mathrm{N}$-terminus and a partial negative charge at the C-terminus [89]. A favored charge-dipole interaction would arise if a negative charge is close to the $\mathrm{N}$-terminus of the helix. 
The conformations of $\mathrm{G}_{3,4} \mathrm{C}^{-}$resemble those of $\mathrm{A}_{3,4} \mathrm{C}^{-}$, and they are mainly globular. Similar to those of $\mathrm{A}_{3,4} \mathrm{CH}$, the effective acidities of $\mathrm{G}_{3,4} \mathrm{CH}$ are largely determined by the effective stabilization effects of the peptide backbone $\mathrm{N}-\mathrm{H}$ groups on the thiolate anion upon deprotonation. Generally speaking, $\mathrm{G}_{3} \mathrm{CH}$ has the acidity similar to that of $\mathrm{A}_{3} \mathrm{CH}\left(\Delta_{\text {acid }} H=332.2 \mathrm{kcal} /\right.$ mol), while $\mathrm{G}_{4} \mathrm{CH}$ is slightly more acidic than $\mathrm{A}_{4} \mathrm{CH}$ $\left(\Delta_{\text {acid }} H=325.9 \mathrm{kcal} / \mathrm{mol}\right)$. An analogue case is the proton affinities of the tripeptides of alanine and glycine. The proton affinities of GlyGlyGly, GlyAlaGly, and GlyGlyAla are about the same. The conformations of both neutral and protonated forms are very similar, mainly coils [90]. The slightly higher acidity of $\mathrm{G}_{4} \mathrm{CH}$ (compared with $\mathrm{A}_{4} \mathrm{CH}$ ) may be because polyglycine chain is more flexible than polyalanine chain, and polyglycine chain can form better coils to stabilize the thiolate anion.

For $\mathrm{CG}_{3,4}{ }^{-}$, in addition to random coils in which the thiolate anions can be stabilized by the available $\mathrm{N}-\mathrm{H}$ groups, a portion of $\mathrm{CG}_{3,4}{ }^{-}$may exist in certain degrees of helices. In these helices, the alignments of the peptide amide bonds are less ordered than those in $\mathrm{CA}_{3,4}{ }^{-}$. It is expected that the thiolate anion in $\mathrm{CG}_{3,4}{ }^{-}$can also be stabilized by interacting with the helix macrodipole, but the effect is smaller than that in $\mathrm{CA}_{3,4}{ }^{-}$. Indeed, the acidities of $\mathrm{N}$-cysteine polyglycine peptides, $\mathrm{CG}_{3,4} \mathrm{H}$, are much stronger than those of $\mathrm{C}$-cysteine polyglycine peptides, $\mathrm{G}_{3,4} \mathrm{CH}$, but are slightly weaker than those of the N-cysteine polyalanine peptides, $\mathrm{CA}_{3,4} \mathrm{H}$.

The gas-phase deprotonation enthalpy of isolated cysteine has been independently measured by several research groups. The value is about $334 \mathrm{kcal} / \mathrm{mol}$. In the deprotonated form of cysteine, the thiolate anion is largely stabilized by forming an intramolecular hydrogen bond with the hydroxyl group $[48,49,51] . \mathrm{CG}_{3} \mathrm{H}$ is about $10 \mathrm{kcal} / \mathrm{mol}$ more acidic than cysteine. The large acidity enhancement can be explained by the increased stabilization effect in the thiolate anion. Adding three glycine units to the carboxyl group of the cysteine will induce a favorable charge-helix dipole interaction. The acidity of $\mathrm{G}_{3} \mathrm{CH}$ is not much stronger than (actually comparable to) that of isolated cysteine. At first it seems unreasonable, since one would expect more hydrogen bonding interactions in $\mathrm{G}_{3} \mathrm{C}^{-}$than in isolated cysteine anion. The explanation might be that in $\mathrm{G}_{3} \mathrm{C}^{-}$the $\mathrm{C}$-terminus is amidated and the stronger hydrogen bonding interaction between the thiolate anion and the carboxyl group (in the cysteine anion) is replaced with weaker ones between the thiolate anion and the backbone NH groups.

Earlier studies on the gas-phase basicities of small peptides suggest that the sequences of the peptides influence the measured basicities [43, 45]. For example, ProGlyGly is more basic than GlyGlyPro [43]. In this case, the peptide does not have a highly basic residue, such as lysine or arginine, and is most likely protonated at the $N$-terminal amino group. Placing the proline at the $N$-terminus can induce stronger hydrogen bonding interaction than does the C-terminus. However, if a peptide contains lysine, the protonation site would be the amino group at the $\omega$-carbon. Further more, if the peptide can form stable helix, then the $C$-terminal lysine peptide is expected to be more basic than the $N$ terminal lysine one.

The entropy terms $\left[\Delta(\Delta S)\right.$, Table 4] for $\mathrm{CG}_{3} \mathrm{H}$ and $\mathrm{G}_{3} \mathrm{CH}$ are relatively small and for $\mathrm{CG}_{4} \mathrm{H}$ and $\mathrm{G}_{4} \mathrm{CH}$ they are moderately small. A small entropy term would lead to a large deprotonation entropy of the peptide. Indeed, the derived deprotonation entropies $(\Delta S$, Table 5) for $\mathrm{CG}_{3} \mathrm{H}$ and $\mathrm{G}_{3} \mathrm{CH}$ are relatively large (18-21 cal/mol K), and for $\mathrm{CG}_{4} \mathrm{H}$ and $\mathrm{G}_{4} \mathrm{CH}$ they are moderately large $(14-15 \mathrm{cal} / \mathrm{mol} \mathrm{K})$. Considering the extensive hydrogen bonding interactions within the peptide anions, one would expect significantly reduced structural flexibility upon deprotonation and, hence, smaller entropies of deprotonation. The relatively large entropies may be explained by the large numbers of possible conformations of the deprotonated as well as the neutral peptides, as reflected from the results of computational studies.

\section{Conclusions}

The gas-phase acidities and related thermochemical quantities of four cysteine-polyglycine peptides, $\mathrm{CG}_{3,4} \mathrm{H}$ and $\mathrm{G}_{3,4} \mathrm{CH}$, were studied quantitatively using the extended Cooks kinetic method with full entropy analysis. The deprotonation enthalpies $\left(\Delta_{\text {acid }} H\right)$ were determined to be $323.9 \pm 2.5 \mathrm{kcal} / \mathrm{mol}\left(\mathrm{CG}_{3} \mathrm{H}\right), 319.2 \pm 2.3$ $\mathrm{kcal} / \mathrm{mol}\left(\mathrm{CG}_{4} \mathrm{H}\right), 333.8 \pm 2.1 \mathrm{kcal} / \mathrm{mol}\left(\mathrm{G}_{3} \mathrm{CH}\right)$, and $321.9 \pm 2.8 \mathrm{kcal} / \mathrm{mol}\left(\mathrm{G}_{4} \mathrm{CH}\right)$. The corresponding deprotonation entropies $\left(\Delta_{\text {acid }} S\right)$ of the peptides were estimated to be $18.3 \mathrm{cal} / \mathrm{mol} \mathrm{K}\left(\mathrm{CG}_{3} \mathrm{H}\right), 14.4 \mathrm{cal} / \mathrm{mol} \mathrm{K}$ $\left(\mathrm{CG}_{4} \mathrm{H}\right), 21.0 \mathrm{cal} / \mathrm{mol} \mathrm{K}\left(\mathrm{G}_{3} \mathrm{CH}\right)$, and $15.1 \mathrm{cal} / \mathrm{mol} \mathrm{K}$ $\left(\mathrm{G}_{4} \mathrm{CH}\right)$. The gas-phase acidities $\left(\Delta_{\text {acid }} G\right)$ were derived to be $318.4 \pm 2.5 \mathrm{kcal} / \mathrm{mol}\left(\mathrm{CG}_{3} \mathrm{H}\right), 314.9 \pm 2.3 \mathrm{kcal} / \mathrm{mol}$ $\left(\mathrm{CG}_{4} \mathrm{H}\right), 327.5 \pm 2.1 \mathrm{kcal} / \mathrm{mol}\left(\mathrm{G}_{3} \mathrm{CH}\right)$, and $317.4 \pm 2.8$ $\mathrm{kcal} / \mathrm{mol}\left(\mathrm{G}_{4} \mathrm{CH}\right)$.

Computational studies show that both neutral and deprotonated peptides could adopt many possible conformations of similar energy. All neutral peptides are mainly random coils. The two $\mathrm{C}$-cysteine anionic peptides, $\mathrm{G}_{3,4} \mathrm{C}^{-}$, are also random coils. The two $\mathrm{N}$-cysteine anionic peptides, $\mathrm{CG}_{3,4}{ }^{-}$, may exist in both random coils and stretched helices.

The two $\mathrm{N}$-cysteine peptides, $\mathrm{CG}_{3} \mathrm{H}$ and $\mathrm{CG}_{4} \mathrm{H}$, are significantly more acidic than the corresponding $\mathrm{C}$ terminal cysteine ones, $\mathrm{G}_{3} \mathrm{CH}$ and $\mathrm{G}_{4} \mathrm{CH}$, by $9 \mathrm{kcal} / \mathrm{mol}$ and $3 \mathrm{kcal} / \mathrm{mol}$, respectively. The stronger acidity of the former may come from the greater stability of the thiolate anion in $\mathrm{CG}_{3,4}{ }^{-}$resulting from the interaction with the helix-macrodipole in addition to the hydrogen bonding interactions. The deprotonation entropies of the four peptides are moderately large, considering the intensive hydrogen bonding interactions within the peptide anion. The relatively large entropies may be 
explained by the fact that the deprotonated peptides can exist in many possible conformations.

\section{Acknowledgments}

The authors acknowledge support for this research by The American Chemical Society Petroleum Research Fund Type-G Grant and the National Science Foundation (CHE-0749737). The instrument usage was provided by the Mass Spectrometry Facility at the University of the Pacific.

\section{Appendix A Supplementary Material}

Supplementary material associated with this article may be found in the online version at doi:10.1016/ j.jasms.2009.12.008.

\section{References}

1. Gitlin, I.; Carbeck, J. D.; Whitesides, G. M. Why are Proteins Charged? Networks of Charge-Charge Interactions in Proteins Measured by Charge Ladders and Capillary Electrophoresis. Angew. Chem. Int. Ed. 2006, 45, 3022-3060.

2. Shoemaker, K. R.; Kim, P. S.; Brems, D. N.; Marqusee, S.; York, E. J.; Chaiken, I. M.; Stewart, J. M.; Baldwin, R. L. Nature of the ChargedGroup Effect on the Stability of the C-Peptide Helix. Proc. Natl. Acad. Sci. U.S.A. 1985, 82, 2349-2353.

3. Shoemaker, K. R.; Kim, P. S.; York, E. J.; Stewart, J. M.; Baldwin, R. L. Tests of the Helix Dipole Model for Stabilization of $\alpha$-Helices. Nature 1987, 326, 563-567.

4. Scholtz, J. M.; Baldwin, R. L. The mechanism of $\alpha$-Helix Formation by Peptides. Annu. Rev. Biophys. Biomol. Struct. 1992, 21, 95-118.

5. Huyghues-Despointes, B. M. P.; Scholtz, J. M.; Baldwin, R. L. Effect of a Single Aspartate on Helix Stability at Different Positions in a Neutral Alanine-Based Peptide. Protein Sci. 1993, 2, 1604-1611.

6. Oommachen, S.; Ren, J.; McCallum, C. M. Stabilizing Helical Polyalanine Peptides with Negative Polarity or Charge: Capping with Cysteine. J. Phys. Chem. B 2008, 112, 5702-5709.

7. Forsyth, W. R.; Antosiewicz, J. M.; Robertson, A. D. Empirical Relationships Between Protein Structure and Carboxyl pKa Values in Proteins. Proteins: Struct. Funct. Genet. 2002, 48, 388-403.

8. Takahashi, N.; Creighton, T. E. On the Reactivity and Ionization of the Active Site Cysteine Residues of Escherichia coli Thioredoxin. Biochemistry 1996, 35, 8342-8353.

9. Gan, Z. R.; Sardana, M. K.; Jacobs, J. W.; Polokoff, M. A. Yeast Thioltransferase- the Active Site Cysteines Display Differential Reactivity. Arch. Biochem. Biophys. 1990, 282, 110-115.

10. Philipps, B.; Glockshuber, R. Randomization of the Entire Active-Site Helix $\alpha 1$ of the Thiol-Disulfide Oxidoreductase DsbA from Escherichia coli. J. Biol. Chem. 2002, 277, 43050-43057.

11. Joshi, H. V.; Meier, M. S. The Effect of a Peptide Helix Macrodipole on the pKa of an Asp side Chain Carboxylate. J. Am. Chem. Soc. 1996, 118, $12038-12044$.

12. Kortemme, T.; Creighton, T. E. Ionization of Cysteine Residues at the Termini of Model a-Helical Peptides. Relevance to Unusual Thiol pKa Values in Proteins of the Thioredoxin Family. J. Mol. Biol. 1995, 253, 799-812.

13. Gallo, E. A.; Gellman, S. H. Effect of a C-Terminal Cationic Group on the Competition between a-Helical Turn and b-Turn in a Model Depsipeptide. J. Am. Chem. Soc. 1994, 116, 11560-11561.

14. Honig, B.; Nicholls, A. Classical Electrostatics in Biology and cChemistry. Science 1995, 268, 1144-1149.

15. Warshel, A. Electrostatic Basis of Structure-Function Correlation in Proteins. Acc. Chem. Res. 1981, 14, 284-290.

16. Whitehouse, C. M.; Dreyer, R. N.; Yamashita, M.; Fenn, J. B. Electrospray Interface for Liquid Chromatographs and Mass Spectrometers. Anal. Chem. 1985, 57, 675-679.

17. Fenn, J. B.; Mann, M.; Meng, C. K.; Wong, S. F.; Whitehouse, C. M. Electrospray Ionization for Mass Spectrometry of Large Biomolecules. Science 1989, 246, 64-71.

18. Nishikaze, T.; Takayama, M. Study of Factors Governing Negative Molecular Ion Yields of Amino Acid and Peptide in FAB, MALDI, and ESI Mass Spectrometry. Int. J. Mass Spectrom. 2007, 268, 47-59.

19. Qin, J.; Chait, B. T. Preferential Fragmentation of Protonated Gas-Phase Peptide Ions Adjacent to Acidic Amino Acid Residues. J. Am. Chem. Soc. 1995, 117, 5411-5412.

20. Gu, C.; Tsaprailis, G.; Breci, L.; Wysocki, V. H. Selective Gas-Phase Cleavage at the Peptide Bond C-Terminal to Aspartic Acid in Fixed-
Charge Derivatives of Asp-Containing Peptides. Anal. Chem. 2000, 72, 5804-5813.

21. Tsaprailis, G.; Somogyi, A.; Nikolaev, E. N.; Wysocki, V. H. Refining the Model for Selective Cleavage at Acidic Residues in Arginine-Containing Protonated Peptides. Int. J. Mass Spectrom. 2000, 195/196, 467-479.

22. Bowie, J. H.; Brinkworth, C. S.; Dua, S. Collision-Induced Fragmentations of the (M-H)-Parent Anions of Underivatized Peptides: An Aid to Structure Determination and Some Unusual Negative Ion Cleavages. Mass Spectrom. Rev. 2002, 21, 87-107.

23. Ewing, N. P.; Cassady, C. J. Dissociation of Multiply Charged Negative Ions for Hirudin (54-65), Fibrinopeptide B, and Insulin A (Oxidized). J. Am. Soc. Mass Spectrom. 2001, 12, 105-116.

24. Harrison, A. G.; Young, A. B. Fragmentation Reactions of Deprotonated Peptides Containing Aspartic Acid. Int. J. Mass Spectrom. 2006, 255-256, 111-122.

25. Dongre, A. R.; Jones, J. L.; Somogyi, A.; Wysocki, V. H. Influence of Peptide Composition, Gas-Phase Basicity, and Chemical Modification on Fragmentation Efficiency: Evidence for the Mobile Proton Model. J. Am. Chem. Soc. 1996, 118, 8365-8374.

26. Harrison, A. G.; Young, A. B. Fragmentation of Protonated Oligoalanines: Amide Bond Cleavage and Beyond. J. Am. Soc. Mass Spectrom. 2004, 15, 1810-1819.

27. Paizs, B.; Suhai, S. Fragmentation Pathways of Protonated Peptides. Mass Spectrom. Rev. 2005, 24, 508-548.

28. Jurchen, J. C.; Cooper, R. E.; Williams, E. R. The Role of Acidic Residues and of Sodium Ion Adduction on the Gas-Phase H/D Exchange of Peptides and Peptide Dimers. Int. J. Mass Spectrom. 2003, 14, 1477-1487.

29. Tsaprailis, G.; Nair, H.; Zhong, W.; Kuppannan, K.; Futrell, J. H.; Wysocki, V. H. A Mechanistic Investigation of the Enhanced Cleavage at Histidine in the Gas-Phase Dissociation of Protonated Peptides. Anal. Chem. 2004, 76, 2083-2094.

30. Bilusich, D.; Brinkworth, C. S.; Bowie, J. H. Negative ion Mass Spectra of Cys-Containing Peptides. The Characteristic Cys g Backbone Cleavage: A Joint Experimental and Theoretical Study. Rapid Commun. Mass Spectrom. 2004, 18, 544-552.

31. Boutin, M.; Bich, C.; Afonso, C.; Fournier, F.; Tabet, J.-C. Negative Charge-Driven Fragmentations for Evidencing Zwitterionic fForms from Doubly Charged Coppered Peptides. J. Mass Spectrom. 2007, 42, 25-35.

32. Lioe, H.; Laskin, J.; Reid, G. E.; O'Hair, R. A. J. Energetics and Dynamics of the Fragmentation Reactions of Protonated Peptides Containing Methionine Sulfoxide or Aspartic Acid Via Energy- and Time-Resolved Surface Induced Dissociation. J. Phys. Chem. A 2007, 111, 10580-10588.

33. Harrison, A. G. The Gas-Phase Basicities and Proton Affinities of Amino Acids and Peptides. Mass Spectrom. Rev. 1997, 16, 201-217.

34. Hahn, I.-S.; Wesdemiotis, C. Protonation Thermochemistry of b-Alanine an Evaluation of Proton Affinities and Entropies Determined by the Extended Kinetic Method. Int. J. Mass Spectrom. 2003, 222, 465-479.

35. Cheng, X.; Wu, Z.; Fenselau, C. Collision Energy Dependence of Proton-Bound Dimer Dissociation: Entropy Effects, Proton Affinities, and Intramolecular Hydrogen-Bonding in Protonated Peptides. J. Am. Chem. Soc. 1993, 115, 4844-4848.

36. Schroeder, O. E.; Andriole, E. J.; Carver, K. L.; Colyer, K. E.; Poutsma J. C. Proton Affinity of Lysine Homologues from the Extended Kinetic Method. J. Phys. Chem. A 2004, 108, 326-332.

37. Bouchoux, G.; Desaphy, S.; Bourcier, S.; Malosse, C.; Bimbong, R. N. B. Gas-Phase Protonation Thermochemistry of Arginine. J. Phys. Chem. B 2008, 112, 3410-3419.

38. Bouchoux, G.; Bimbong, R. N. B.; Nacer, F. Gas-Phase Protonation Thermochemistry of Glutamic Acid. J. Phys. Chem. A 2009, 113, 66666676.

39. Sunderlin, L. S.; Ryzhov, V.; Keller, L. M. M.; Gaillard, E. R. Measuring Gas-Phase Basicities of Amino Acids Using an Ion Trap Mass Spectrometer. A Physical Chemistry Laboratory Experiment. J. Chem. Educ. 2005, 82, 1071-1073.

40. Wind, J. J.; Papp, L.; Happel, M.; Hahn, K.; Andriole, E. J.; Poutsma, J. C. Proton Affinity of $\beta$-Oxalylaminoalanine (BOAA): Incorporation of Direct Entropy Correction into the Single-Reference Kinetic Method. J. Am. Soc. Mass Spectrom. 2005, 16, 1151-1161.

41. Kaltashov, I. A.; Fabris, D.; Fenselau, C. C. Assessment of Gas Phase Basicities of Protonated Peptides by the Kinetic Method. J. Phys. Chem. 1995, 99, 10046-10051.

42. Chung-Phillips, A. Polyglycine Conformational Analysis: Calculated vs. Experimental Gas-Phase Basicities and Proton Affinities. J. Phys. Chem. A 2005, 109, 5917-5932.

43. Ewing, N. P.; Zhang, X.; Cassady, C. J. Determination of the Gas-Phase Basicities of Proline and Its Di- and Tripeptides with Glycine: The Enhanced Basicity of Prolylproline. J. Mass Spectrom. 1996, 31, 13451350 .

44. Zhang, K. Zimmerman, D. M.; Chung-Phillips, A.; Cassady, C. J. Experimental and $\mathrm{Ab}$ Initio Studies of the Gas-Phase Basicities of Polyglycines. J. Am. Chem. Soc. 1993, 115, 10812-10822.

45. McKiernan, J. W.; Beltrame, C. E. A.; Cassady, C. J. Gas-Phase Basicities of Serine and Dipeptides of Serine and Glycine. J. Am. Soc. Mass Spectrom. 1994, 5, 718-723.

46. Caldwell, G. W.; Renneboog, R.; Kebarle, P. Gas-Phase Acidities of Aliphatic Carboxylic Acids Based on Measurements of Proton-Transfer Equilibria. Can. J. Chem. 1989, 67, 611-618.

47. Locke, M. J.; McIver, R. T. Jr. Effect of Solvation on the Acid/Base Properties of Glycine. J. Am. Chem. Soc. 1983, 105, 4226-4232. 
48. Jones, C. M.; Bernier, M.; Carson, E.; Colyer, K. E.; Metz, R.; Pawlow, A.; Wischow, E. D.; Webb, I.; Andriole, E. J.; Poutsma, J. C. Gas-Phase Acidities of the 20 Protein Amino Acids. Int. J. Mass Spectrom. 2007, 267 $54-62$.

49. Tian, Z.; Pawlow, A.; Poutsma, J. C.; Kass, S. R. Are Carboxyl Groups the Most Acidic Sites in Amino Acids? Gas-Phase Acidity, H/D Exchange Experiments, and Computations on Cysteine and its Conjugate Base. J. Am. Chem. Soc. 2007, 129, 5403-5407.

50. Li, Z.; Matus, M. H.; Velazquez, H. A.; Dixon, D. A.; Cassady, C. J. Gas-Phase Acidities of Aspartic Acid, Glutamic Acid, and Their Amino Acid Amides. Int. J. Mass Spectrom. 2007, 265, 213-223.

51. O'Hair, R. A. J.; Bowie, J. H.; Gronert, S. Gas Phase Acidities of the $\alpha$ amino acids. Int. J. Mass Spectrom. Ion Processes 1992, 117, 23-36.

52. Fournier, F.; Afonso, C.; Fagin, A. E.; Gronert, S.; Tabet, J.-C. Can Cluster Structure Affect Kinetic Method Measurements? The Curious Case of Glutamic Acid's Gas-Phase Acidity. J. Am. Soc. Mass Spectrom. 2008, 19, 1887-1896.

53. Jia, B.; Angel, L. A.; Ervin, K. M. Threshold Collision-Induced Dissociation of Hydrogen-Bonded Dimers of Carboxylic Acids. J. Phys. Chem. A 2008, 112, 1773-1782.

54. Woo, H.-K.; Lau, K.-C.; Wang, X.-B.; Wang, L.-S. Observation of Cysteine Thiolate and -S.H-O Intramolecular Hydrogen Bond. J. Phys. Chem. A 2006, 110, 12603-12606.

55. Carr, S. R.; Cassady, C. J. Reactivity and Gas-Phase Acidity Determinations of Small Peptide Ions Consisting of 11 to 14 Amino Acid Residues. J. Mass Spectrom. 1997, 32, 959-967.

56. Tan, J. P.; Ren, J. Determination of the Gas-Phase Acidities of CysteinePolyalanine Peptides Using the Extended Kinetic Method. J. Am. Soc. Mass Spectrom. 2007, 18, 188-194.

57. Ren, J.; Tan, J. P.; Harper, R. T. Gas-Phase Acidities of CysteinePolyalanine Peptides I: $\mathrm{A}_{3,4} \mathrm{CSH}$, and $\mathrm{HSCA}_{3,4}$. J. Phys. Chem. A 2009, 113, 10903-10912.

58. Chakrabartty, A.; Schellman, J. A.; Baldwin, R. L. Large Differences in the Helix Propensities of Alanine and Glycine. Nature 1991, 351, $586-588$.

59. Hudgins, R. R.; Jarrold, M. F. Helix Formation in Unsolvated AlanineBased Peptides: Helical Monomers and Helical Dimers. J. Am. Chem. Soc. 1999, 121, 3494-3501.

60. Hudgins, R. R.; Jarrold, M. F. Conformations of Unsolvated GlycineBased Peptides. J. Phys. Chem. B 2000, 104, 2154-2158.

61. Counterman, A. E.; Clemmer, D. E. Gas Phase Polyalanine: Assessment of $\mathrm{i} \rightarrow \mathrm{i}+3$ and $\mathrm{i} \rightarrow \mathrm{i}+4$ Helical Turns in [Alan $+4 \mathrm{H}] 4+(n=29-49)$ Ion. J. Phys. Chem. B 2002, 106, 12045-12051.

62. Cooks, R. G.; Patrick, J. S.; Kotiaho, T.; McLuckey, S. A. Thermochemical Determinations by the Kinetic Method. Mass Spectrom. Rev. 1994, 13, 287-339.

63. Cooks, R. G.; Wong, P. S. H. Kinetic Method of Making Thermochemical Determinations: Advances and Applications. Acc. Chem. Res. 1998, 31, 379-386.

64. Cooks, R. G.; Koskinen, J. T.; Thomas, P. D. The Kinetic Method of Making Thermochemical Determinations. J. Mass Spectrom. 1999, 34, 85-92.

65. Cerda, B. A.; Wesdemiotis, C. $\mathrm{Li}^{+}, \mathrm{Na}^{+}$, and $\mathrm{K}^{+}$Binding to the DNA and RNA Nucleobases. Bond Energies and Attachment Sites from the Dissociation of Metal Ion-Bound Heterodimers. J. Am. Chem. Soc. 1996, $118,11884-11892$.

66. Bouchoux, G.; Sablier, M.; Berruyer-Penaud, F. Obtaining Thermochemical Data by the Extended Kinetic Method. J. Mass Spectrom. 2004, 39, 986-997.

67. Zheng, X.; Cooks, R. G. Thermochemical Determinations by the Kinetic Method with Direct Entropy Correction. J. Phys. Chem. A 2002, 106, 9939-9946.

68. Drahos, L.; Vekey, K. How Closely Related are the Effective and the Real Temperature. J. Mass Spectrom. 1999, 34, 79-84.

69. Drahos, L.; Peltz, C.; Vekey, K. Accuracy of Enthalpy and Entropy Determination Using the Kinetic Method: Are We Approaching a Consensus? J. Mass Spectrom. 2004, 39, 1016-1024.

70. Armentrout, P. B. Is the Kinetic Method a Thermodynamic Method? J. Mass Spectrom. 1999, 34, 74-78.

71. Laskin, J.; Futrell, J. H. The Theoretical Basis of the Kinetic Method from the Point of View of Finite Heat Bath Theory. J. Phys. Chem. A 2000, 104, 8829-8837.
72. Ervin, K. M. Microcanonical Analysis of the Kinetic Method. The Meaning of the "Apparent Entropy". J. Am. Soc. Mass Spectrom. 2002, 13, $435-452$.

73. Norrman, K.; McMahon, T. B. Relationship Between Effective Temperature of Thermalized Ions and Ion Source Temperature. Int. J. Mass Spectrom. 1998, 176, 87-97.

74. Meot-Ner, M.; Somogyi, A. A Thermal Extrapolation Method for the Effective Temperatures and Internal Energies of Activated Ions. Int. J. Mass Spectrom. 2007, 267, 346-356.

75. Armentrout, P. B. Entropy Measurements and the Kinetic Method: A Statistically Meaningful Approach. J. Am. Soc. Mass Spectrom. 2000, 11, 371-379.

76. Ervin, K. M.; Armentrout, P. B. Systematic and Random Errors in Ion Affinities and Activation Entropies from the Extended Kinetic Method. J. Mass Spectrom. 2004, 39, 1004-1015.

77. Gutte, B. Ed. Peptides: Synthesis, Structures, and Applications; Academic: San Diego, CA, 1995.

78. Barany, G.; Merrifield, R. B. Solid-Phase Peptide Synthesis. Peptides. 1980, 2, 1-284.

79. Chan W. C.; White P. D. Eds. Fmoc Solid Phase Peptide Synthesis: A Practical Approach; Oxford University Press: Oxford, UK, 2000.

80. Dewar, M. J. S.; Zoebisch, E. G.; Healy, E. F.; Stewart, J. J. P. Development and Use of Quantum Mechanical Molecular Models. 76. AM1: A New General Purpose Quantum Mechanical Molecular Model. J. Am. Chem. Soc. 1985, 107, 3902-3909.

81. Parr R. G. Ed. Density-functional Theory of Atoms and Molecules; Oxford University Press: Oxford, UK, 1989.

82. Becke, A. D. Density-Functional Exchange-Energy Approximation with Correct Asymptotic Behavior. Phys. Rev. A 1988, 38, 3098-3100.

83. Becke, A. D. Density-Functional Thermochemistry. III. The Role of Exact Exchange. J. Chem. Phys. 1993, 98, 5648-5652.

84. Lee, C.; Yang, W.; Parr, R. G. Development of the Colle-Salvetti Correlation-Energy Formula into a Functional of the Electron Density. Phys. Rev. B 1988, 37, 785-789.

85. Frisch, M. J.; Trucks, G. W.; Schlegel, H. B.; Scuseria, G. E.; Robb, M. A.; Cheeseman, J. R.; J. A. Montgomery, J.; Vreven, T.; Kudin, K. N.; Burant, J. C.; Millam, J. M.; Iyengar, S. S.; Tomasi, J.; Barone, V.; Mennucci, B. Cossi, M.; Scalmani, G.; Rega, N.; Petersson, G. A.; Nakatsuji, G.; Hada, M.; Ehara, M.; Toyota, K.; Fukuda, R.; Hasegawa, J.; Ishida, M.; Nakajima, T.; Honda, Y.; Kitao, O.; Nakai, H.; Klene, M.; Li, X.; Knox, J. E.; Hratchian, H. P.; Cross, J. B.; Adamo, C.; Jaramillo, J.; Gomperts, R.; Stratmann, R. E.; Yazyev, O.; Austin, A. J.; Cammi, R.; Adamo, C. Jaramillo, J.; Gomperts, R.; Stratmann, R. E.; Yazyev, O.; Austin, A. J.; Cammi, R.; Pomelli, C.; Ochterski, J. W.; Ayala, P. Y.; Morokuma, K.; Voth, G. A.; Salvador, P.; Dannenberg, J. J.; Zakrzewski, V. G.; Dapprich, S.; Daniels, A. D.; Strain, M. C.; Farkas, O.; Malick, D. K.; Rabuck, A. D.; Raghavachari, K.; Foresman, J. B.; Ortiz, J. V.; Cui, Q.; Baboul, A. G.; Cliford, S.; Cioslowski, J.; Stefanov, B. B.; Liu, G.; Liashenko, A.; Piskorz, P.; Komaromi, I.; Martin, R. L.; Fox, D. I.; Keith, T.; Al-Laham, M. A.; Peng, C. Y.; Nanayakkara, A.; Challacombe, M.; Gill, P. M. W.; Johnson, B.; Chen, W.; Wong, M. W.; Gonzalez, C.; Pople, J. A. Gaussian 03, Revision A 1; Gaussian, Inc.: Pittsburgh, PA, 2003

86. Boggs, P. T.; Byrd, R. H.; Rogers, J. E.; Schnabel, R. B. ODRPACK Version 2.01 Software for Weighted Orthogonal Distance Regression. Report NISTIR 92-4834. National Institute of Standards and Technology: Gaithersburg, MD, 1992.

87. $\mathrm{Wu}, \mathrm{Z}$.; Fenselau, C. Proton Affinities of Polyglycines Assessed by Using the Kinetic Method. J. Am. Soc. Mass Spectrom. 1992, 3, 863-866.

88. Wu, J.; Lebrilla, C. B. Gas-Phase Basicities and Sites of Protonation of Glycine Oligomers (Gly $; n=1-5)$. J. Am. Chem. Soc. 1993, 115, 3270-3275.

89. Hol, W. G.; van Duijnen, P. T.; Berendsen, H. J. The $\alpha$-Helix Dipole and the Properties of Proteins. Nature 1978, 273, 443-446.

90. Cassady, C. J.; Carr, S. R.; Zhang, K.; Chung-Phillips, A. Experimental and $\mathrm{Ab}$ Initio Studies on Protonations of Alanine and Small Peptides of Alanine and Glycine. J. Org. Chem. 1995, 60, 1704-1712.

91. NIST Chemistry WebBook, NIST Standard Reference Database Number 69; Linstrom, P. J.; Mallard, W. G., Eds.; National Institute of Standards and Technology: Gaithersburg, MD (http://webbook.nist.gov). 